\section{D) Check for updates}

Cite this: Dalton Trans., 2021, 50 , 14695

Received 5th July 2021, Accepted 17th September 2021 DOI: 10.1039/d1dt02224e rsc.li/dalton

\title{
Synthesis and ex vivo biological evaluation of gallium-68 labelled NODAGA chelates assessing cardiac uptake and retention $\uparrow$
}

\author{
Bradley E. Osborne, (D) ${ }^{a, b}$ Thomas T. C. Yue, (D) ${ }^{a}$ Edward C. T. Waters, ${ }^{b}$ \\ Friedrich Baark, ${ }^{\mathrm{b}}$ Richard Southworth (D) ${ }^{\mathrm{b}}$ and Nicholas J. Long (D) *a
}

\begin{abstract}
Radiolabelled lipophilic cations can be used to non-invasively report on mitochondrial dysfunction in diseases such as cardiovascular disease, cardiotoxicity and cancer. Several such lipophilic cations are currently used clinically to map myocardial perfusion using SPECT imaging. Since PET offers significant advantages over SPECT in terms of sensitivity, resolution and the capacity for dynamic imaging to allow pharmacokinetic modelling, we have synthesised and radiolabelled a series of NODAGA-based radiotracers, with triarylphosphonium-functionalisation, with gallium-68 to develop PET-compatible cationic complexes. To evaluate their capacity to report upon mitochondrial membrane potential, we assessed their pharmacokinetic profiles in isolated perfused rat hearts before and after mitochondrial depolarisation with the ionophore CCCP. All three tracers radiolabel with over $96 \% \mathrm{RCY}$, with $\log D_{7.4}$ values above -0.4 observed for the most lipophilic example of this family of radiotracers. The candidate tracer $\left[{ }^{68} \mathrm{Ga}\right] \mathrm{Ga} 4 \mathrm{c}$ exhibited non-preferential uptake in healthy cardiac tissue over CCCP-infused cardiac tissue. While this approach does show promise, the lipophilicity of this family of probes needs improving in order for them to be effective cardiac imaging agents.
\end{abstract}

\section{Introduction}

The radiolabelled lipophilic cations $\left[{ }^{99 \mathrm{~m}} \mathrm{Tc}\right] \mathrm{Tc}$-sestaMIBI (Fig. 1) and $\left[{ }^{99 \mathrm{~m}} \mathrm{Tc}\right] \mathrm{Tc}$-tetrofosmin are widely used clinically to visualise defects in myocardial perfusion using single photon emission computed tomography (SPECT) ${ }^{1-4}$ While the delivery of these imaging agents to tissues is dependent upon perfusion, as cations, their retention within mitochondria is actually determined by mitochondrial membrane potential $\left(\Delta \Psi_{\mathrm{m}}\right)-$ dependent trapping according to the Nernst equation..$^{5-7}$ Accordingly, if the retention of such lipophilic cations could be corrected for perfusion, either by pharmacokinetic modelling or by parallel injection of non-mitochondrially dependent perfusion imaging agents, they could be repurposed to provide a non-invasive imaging index on mitochondrial dysfunction in cancer and cardiovascular disease, as we have recently proposed..$^{8}$

\footnotetext{
${ }^{a}$ Department of Chemistry, Imperial College London, Molecular Sciences Research Hub, White City Campus, Wood Lane, London, W12 OBZ, UK.

E-mail: n.long@imperial.ac.uk

${ }^{b}$ School of Biomedical Engineering and Imaging Sciences, King's College London, 4th Floor Lambeth Wing, St Thomas' Hospital, London, SE1 TEH, UK.

E-mail: richard.southworth@kcl.ac.uk

$\dagger$ Electronic supplementary information (ESI) available. See DOI: 10.1039/ d1dt02224e
}

Positron emission tomography (PET) offers significant advantages over SPECT in terms of spatial resolution, sensitivity, and the capacity for dynamic imaging to allow pharmacokinetic modelling and 3-dimensional image-derived perfusion correction or parameter mapping. Translating this class of perfusion imaging agents to PET is therefore an attractive prospect. Lipophilic triphenylphosphonium (TPP)-functionalised compounds are also capable of targeting the mitochondria due to their delocalised positive charge across the large surface area of the aromatic rings, and TPP-based PET tracers radiolabelled with carbon- 11 and fluorine- $18\left(t_{\frac{1}{2}}=20\right.$ and 109.7 min respectively) have been extensively explored for
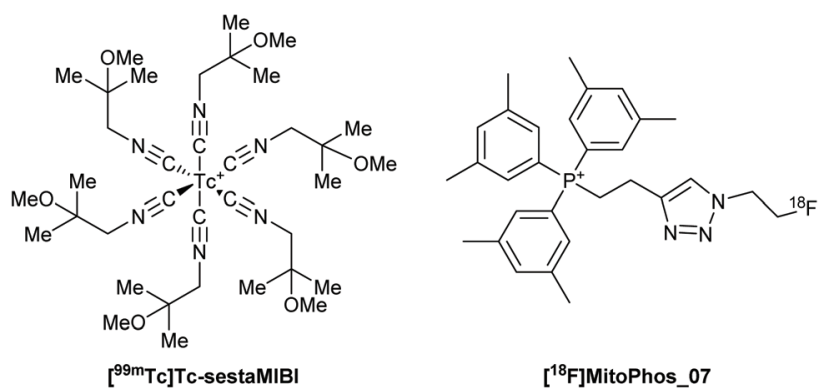

$\left[{ }^{18} \mathrm{~F}\right]$ MitoPhos_07

Fig. $1\left[{ }^{99 m}\right.$ Tc]Tc-sestaMIBI and $\left[{ }^{18} \mathrm{~F}\right]$ MitoPhos_07, two examples of lipophilic and cationic radiotracers. ${ }^{1,19}$ 
mitochondrial imaging. ${ }^{9-18}$ In 2014 , Haslop et al. synthesised a series of fluorine-18 radiolabelled compounds, $\left[{ }^{18} \mathrm{~F}\right]$ MitoPhos (Fig. 1), consisting of alkyl-functionalised motifs on triarylphosphonium (TAP) moieties, achieved via a copper-catalysed click reaction of an ${ }^{18} \mathrm{~F}$ synthon to the TAP cation. ${ }^{19}$ Functionalisation of the TAP moiety afforded the tuneability of radiotracer lipophilicity which facilitated the modification of its pharmacokinetic properties and capacity to successfully penetrate cell membranes.

The recent development and clinical approval of ${ }^{68} \mathrm{Ge} /{ }^{68} \mathrm{Ga}$ generators to produce the positron-emitting radiometal gallium-68, has provided the opportunity for clinical PET imaging without the expensive infrastructure required for cyclotron-produced radioisotopes like fluorine-18 and carbon11. ${ }^{20,21}$ Gallium-68 also affords a convenient balance between patient radiation dosage and effective imaging due to its halflife $\left(t_{\frac{1}{2}}=68 \mathrm{~min}\right)$. The first use of gallium radionuclides in lipophilic cations was reported by Sharma et al., in 2014, who developed a Schiff-base phenolic complex, consisting of a gallium-68 metal core surrounded by aromatic and isopropoxide groups. ${ }^{22}$ In 2017, Kardashinsky et al. synthesised a series of TAP-functionalised DO3A compounds for the gamma-emitting radionuclide gallium-67 $\left(t_{\frac{1}{2}}=78 \mathrm{~h}\right)$, which consisted of methyl and methoxy aryl functionalisation, as well as monoiodo and pyridyl asymmetric variants. ${ }^{23}$ In 2018, Smith et al. synthesised a family of DO3A-xy-TAP chelates for gallium-68, functionalised with triphenylphosphonium (TPP), tritolylphosphonium (TTP) and trixylylphosphonium (TXP). ${ }^{24}$ These radiotracers were designed with the idea of combining the tuneable lipophilicity afforded by alkyl-functionalisation of the TAP moiety, and the rationale behind the DO3A-xy-TPP chelators used for gallium-67. ${ }^{23}$ The most lipophilic tracers of this series, $\left[{ }^{68} \mathbf{G a}\right]$ Ga-DO3A-xy-TXP (Fig. 2), was assessed in vitro in cultured tumour cells, and exhibited a three-fold increase in uptake compared to unchelated $\left[{ }^{68} \mathrm{Ga}\right] \mathrm{Ga}(\mathrm{III})$. The capacity of this radiotracer to report on mitochondrial membrane potential was assessed ex vivo in isolated perfused rat hearts, which exhibited less than 1\% retention in healthy hearts (compared to approximately $40 \%$ uptake typically observed with the "gold standard" $\left[{ }^{99 \mathrm{~m}} \mathrm{Tc}\right] \mathrm{Tc}$-sestaMIBI $) .{ }^{8}$ This was not significantly reduced by mitochondrial depolarisation with the ionophore carbonyl cyanide $m$-chlorophenyl hydrazone (CCCP), suggesting the lipophilicity of this family $\left(\log D_{7.4}\right.$ between -3.12 and -1.81 ) was insufficient to penetrate cell membranes to reach the mitochondria. In 2020, Smith et al. attempted to address this limitation by synthesising and radiolabelling two series of DO2A-based chelates with bisTAP- and bisaryl-functionalisation, resulting in $\log D_{7.4}$ values of -0.3 for the most lipophilic examples, $\left[{ }^{68} \mathrm{Ga}\right] \mathrm{Ga}-\mathrm{DO} 2 \mathrm{~A}-(\mathrm{xy}-\mathrm{TXP})_{2}$ and $\left[{ }^{68} \mathrm{Ga}\right] \mathrm{Ga}$ $\mathrm{DO} 2 \mathrm{~A}-\mathrm{Xy}_{2}$ (Fig. 2). ${ }^{25}$ Both sets of tracers radiolabelled with over $90 \%$ radiochemical purity (RCP) when heated at $100{ }^{\circ} \mathrm{C}$ for $30 \mathrm{~min}$, however formation of kinetic/thermodynamic pairs of species were observed upon gallium-68 chelation which were visualised and separated by radioHPLC. These tracers exhibited much improved retention in healthy hearts compared to their respective DO3A analogues, and their cardiac washout following

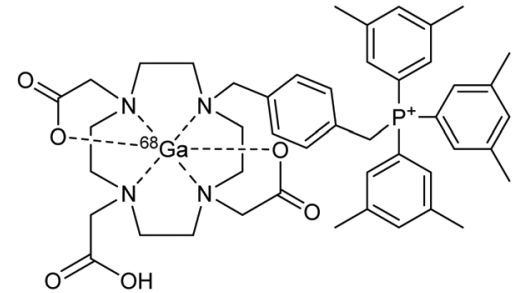

\section{$\left[{ }^{68} \mathrm{Ga}\right] \mathrm{Ga}-\mathrm{DO} 3 \mathrm{~A}-\mathrm{-xy}-\mathrm{TXP}$}
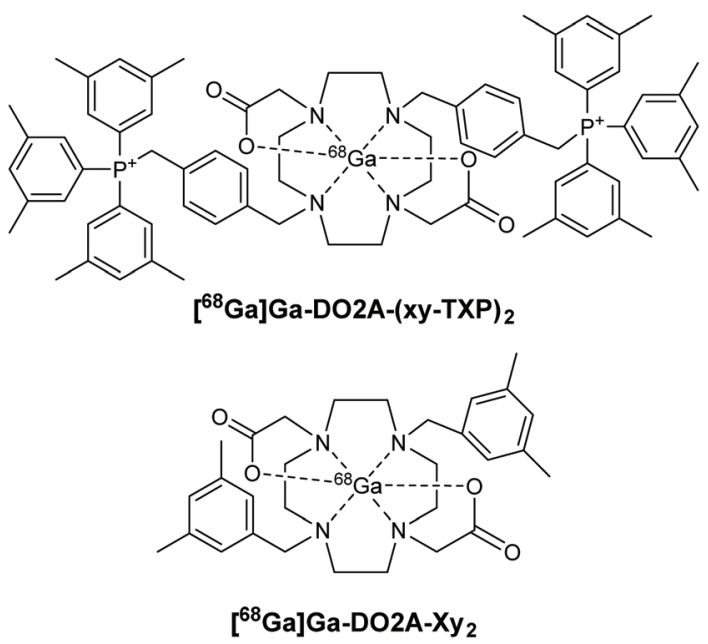

Fig. 2 [ $\left.{ }^{68} \mathrm{Ga}\right] \mathrm{Ga}-\mathrm{DO} 3 \mathrm{~A}-\mathrm{xy}-\mathrm{TXP}, \quad\left[{ }^{68} \mathrm{Ga}\right] \mathrm{Ga}-\mathrm{DO} 2 \mathrm{~A}-(\mathrm{xy}-\mathrm{TXP})_{2}$ and $\left[{ }^{68} \mathrm{Ga}\right]$ Ga-DO2A- $\mathrm{Xy}_{2}$, three examples of gallium-68 lipophilic and cationic radiotracers synthesised in our group. ${ }^{24,25}$

mitochondrial depolarisation with infusion of CCCP suggested a $\Delta \Psi_{\mathrm{m}}$-dependent component in their cardiac uptake and retention. However, these tracers retained significant non-specific cardiac retention, which limits their usefulness.

The harsh radiolabelling conditions needed for successful ${ }^{68}$ Ga-labelling of the DO3A- and DO2A-based chelates were a result of the size mismatch of these macrocyclic chelates and $\mathrm{Ga}$ (III), and increased the overall hydrophilicity of these complexes, with the unbound carboxylate arm present in the Ga-DO3A complexes exhibiting low $\log D_{7.4}$ values. In order to address these limitations, we have herein developed a series of (R)-NODAGAbased ligands for gallium-68 chelation for the formation of ${ }^{68}$ Ga-labelled cationic complexes, which are presented in this study (Fig. 3). The chosen chelator for this study, (R)-NODAGA, displays the appropriate hexadentate coordination environment necessary for Ga(III) whilst providing a better size match between NODAGA and Ga(III), leading to significantly improved radiolabelling kinetics and stability of Ga-labelled compounds. $^{26,27}$ The absence of an unbound carboxylate arm will increase the overall lipophilicity of the final radiotracers.

By combining the rationales discussed above, we have synthesised three (R)-NODAGA-based chelators with tuneable lipophilicity afforded by alkyl-functionalised TAP moieties in order to form the novel ligands (R)-NODAGA-xy-TPP, (R)-NODAGA-xyTTP and (R)-NODAGA-xy-TXP. After the synthesis and characterisation of the ligands, their radiolabelling profiles with gallium68 and $\log D_{7.4}$ values were assessed as an initial indication of 


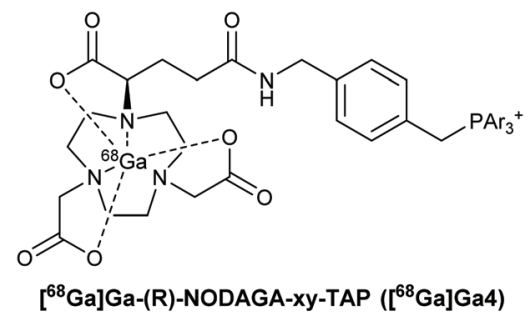<smiles>[Al+4]Cc1ccccc1</smiles>

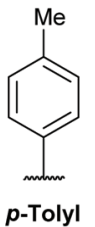

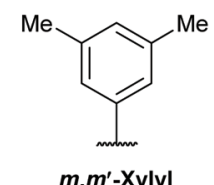

Fig. 3 The three $\left[{ }^{68} \mathrm{Ga}\right] \mathrm{Ga}-(\mathrm{R})-N O D A G A-b a s e d$ radiotracers investigated in this study; (R)-NODAGA-xy-TAP, and the phenyl, $p$-tolyl and $m, m^{\prime}$-xylyl motifs used.

their capacity to report on mitochondrial dysfunction. The pharmacokinetics and sensitivity of the tracers to $\Delta \Psi_{\mathrm{m}}$ were then evaluated using the ex vivo Langendorff isolated heart model monitored by our triple $\gamma$-detection system. ${ }^{24,25,28-31}$

\section{Results and discussion}

\section{Synthesis of (R)-NODAGA-xy-TAP chelators}

Building on our previous work on the synthesis of DO3A-xyTAP, DO2A-(xy-TAP) $)_{2}$ and DO2A-Ar ${ }_{2}$ chelators, (R)-NODAGA-xyTAP (4) ligands with triphenylphosphonium (TPP, 4a), tritolylphosphonium (TTP, 4b) and trixylylphosphonium (TXP, 4c) functionalisation were synthesised as illustrated in Scheme 1.
The synthesis of $\mathbf{4 a}-\mathbf{c}$ combined methodologies used by Eisenwiener et al., Smith et al. and Schirrmacher et al. ${ }^{25,32,33}$ Firstly the TAP-functionalised bromoxylenes 1a-c, were reacted with aqueous ammonia in ethanol to form the TAP-functionalised aminoxylenes 2a-c. The monocationic aminoxylene phosphonium species 2 was then reacted with tris-tert-butyl-protected (R)-NODAGA to form TAP-functionalised NODAGA derivatives (3). Due to the insolubility of the TAP-functionalised aminoxylenes (2) in organic solvents, we performed the reaction in a 50:50 mixture of water and acetonitrile using $N, N^{\prime}$-dicyclohexylcarbodiimide (DCC) as the coupling reagent, as a modification of the procedure used by Schirrmacher et $a l .{ }^{33}$ DCC was dissolved in pyridine and added in a dropwise manner to the reaction mixture, activating the carboxylic acid and providing a base for the reaction. The byproduct of this amide coupling, dicyclohexylurea (DCU), was easily isolated and removed by filtration by dissolving the crude residue in acetonitrile, which DCU is highly insoluble in. The protected intermediates $(\mathbf{3 a - c})$ were purified by reverse-phase flash chromatography, followed by deprotection of the tert-butyl protected carboxylates in trifluoroacetic acid (TFA) and purification using reverse-phase flash chromatography to obtain the final ligands $(\mathbf{4 a - c})$. The modular approach used in this work allows for a library of compounds to be synthesised and purified in a simple manner, utilising identical reaction protocols.

\section{Radiolabelling studies of (R)-NODAGA-xy-TAP chelates with $\left[{ }^{68} \mathrm{Ga}\right] \mathrm{GaCl}_{3}$ eluate}

All three (R)-NODAGA-xy-TAP compounds were radiolabelled and analysed according to the same protocol, a modification of the methodology previously described by Smith et al. ${ }^{24,25}$

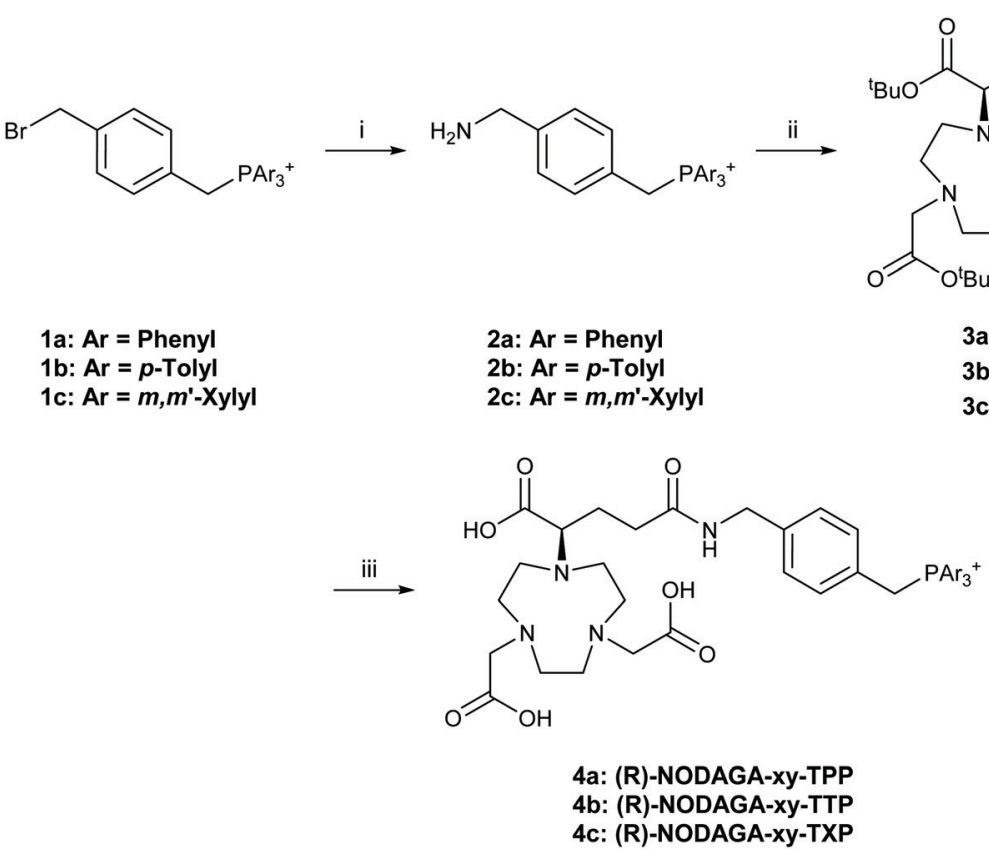

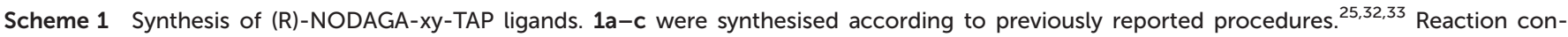

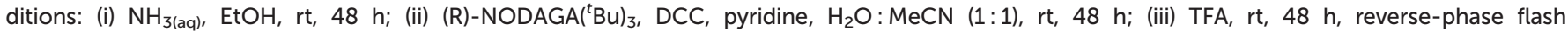
chromatography. 
The ligand was dissolved in clinical grade $3.6 \mathrm{M}$ NaOAc to generate a ligand concentration of $500 \mu \mathrm{M}$, before adding generator-produced $\left[{ }^{68} \mathrm{Ga}\right] \mathrm{Ga}$ (III) (in $0.1 \mathrm{M}$ aqueous $\mathrm{HCl}, 500 \mu \mathrm{L}$ ) and the resulting mixture $(\mathrm{pH} 5.0)$ was left at room temperature for 15 minutes. Instant thin-layer chromatography (iTLC) was employed as a quality control (QC) method. Two different mobile phases were employed for iTLC: (1) 0.1 M EDTA $\left[{ }^{68} \mathrm{Ga}\right] \mathrm{Ga}$-(R)-NODAGA-xy-TAP $R_{\mathrm{f}}<0.1$; unchelated $\left[{ }^{68} \mathrm{Ga}\right] \mathrm{Ga}(\mathrm{III})$ $R_{\mathrm{f}}>0.9$. (2) $2.0 \mathrm{M} \mathrm{NH}_{4} \mathrm{OAc}: \mathrm{MeOH}(1: 1)$ - unchelated $\left[{ }^{68} \mathrm{Ga}\right] \mathrm{Ga}$ (III) $\quad R_{\mathrm{f}}<0.1 ; \quad\left[{ }^{68} \mathrm{Ga}\right] \mathrm{Ga}-(\mathrm{R})-N O D A G A-x y-T A P \quad R_{\mathrm{f}}=0.6-0.7$. Implementing this method for the QC of ${ }^{68} \mathrm{Ga}$-labelling with these compounds provides the basis for analysing future gallium68 labelled lipophilic and cationic radiotracers due to the facile chelation of $\mathrm{Ga}(\mathrm{III})$ by EDTA, along with promotion of ${ }^{68} \mathrm{Ga}$ labelled radiotracers to the solvent front by a 1-to-1 mixture of 2.0 $\mathrm{M} \mathrm{NH}_{4} \mathrm{OAc}: \mathrm{MeOH}$. In order to determine the efficiency of gallium-68 chelation, a series of reactions were undertaken in which the $\left[{ }^{68} \mathrm{Ga}\right] \mathrm{Ga}$ (III) eluate was added to a solution of ligand in 3.6 $\mathrm{M} \mathrm{NaOAc}(42 \mu \mathrm{L})$ at a ligand concentration in the range $500 \mu \mathrm{M}$ to $5 \mu \mathrm{M}$. After 15 minutes reaction time and room temperature, radiochemical yields (RCY) were measured using iTLC, with a ligand concentration of $100 \mu \mathrm{M}$, RCYs were greater than $97 \%$ for $\left[{ }^{68} \mathrm{Ga}\right] \mathrm{Ga}-(\mathrm{R})-\mathrm{NODAGA}-\mathrm{xy}-\mathrm{TPP}$, TTP and TXP. At a ligand concentration of $50 \mu \mathrm{M}$, RCYs were greater than $85 \%$ for all radiolabelled compounds, and at a ligand concentration of $5 \mu \mathrm{M}$, RCYs of less than $50 \%$ were obtained. Due to near quantitative RCYs obtained for all ${ }^{68}$ Ga-labelled complexes at $100 \mu \mathrm{M}$ ligand concentration, this ligand concentration was used to perform myocardial uptake and retention experiments due to there being no requirement for post-purification at this concentration.

To assess the purity of the obtained ${ }^{68} \mathrm{Ga}$-radiolabelled complexes, the reaction mixture was analysed by radioHPLC. This also serves as an initial indication of radiotracer lipophilicity. The traces obtained for all three compounds are shown normalised form in Fig. 4A, with the HPLC traces of their respective proligands shown in Fig. 4B. Unreacted/non-chelated $\left[{ }^{68} \mathrm{Ga}\right] \mathrm{Ga}$ (III) species were identified as a small peak in all HPLC traces, observed at approximately 2 minutes, and the desired complexes corresponded to a single major peak with no evidence of any isomerism. Fig. 4 illustrates that an increase in TAP alkylation results in a longer retention time and indicates superior lipophilicity, with the retention times determined to be $15.8 \mathrm{~min}, 18.0 \mathrm{~min}$ and $19.6 \mathrm{~min}$ for ${ }^{68} \mathrm{Ga}$-labelled NODAGA-xyTPP, TTP and TXP respectively. This finding is further supported by the HPLC traces of the proligands; retention times found to be $11.8 \mathrm{~min}, 14.1 \mathrm{~min}$ and $15.4 \mathrm{~min}$ for NODAGA-xy-TPP, TTP and TXP respectively. The proligands also show shorter retention times by HPLC than their radiolabelled analogues, demonstrating an increase in lipophilicity upon chelation with gallium-68, resulting from a reduction in hydrophilic interactions of the carboxylate arms upon binding with Ga(III).

\section{Lipophilicity measurements of $\left[{ }^{68} \mathrm{Ga}\right] \mathrm{Ga}-N O D A G A-x y-T A P$ radiotracers}

Lipophilicities of the radiotracers were measured from their octanol/PBS partition coefficients at pH $7.4(\log D)$ using a con-
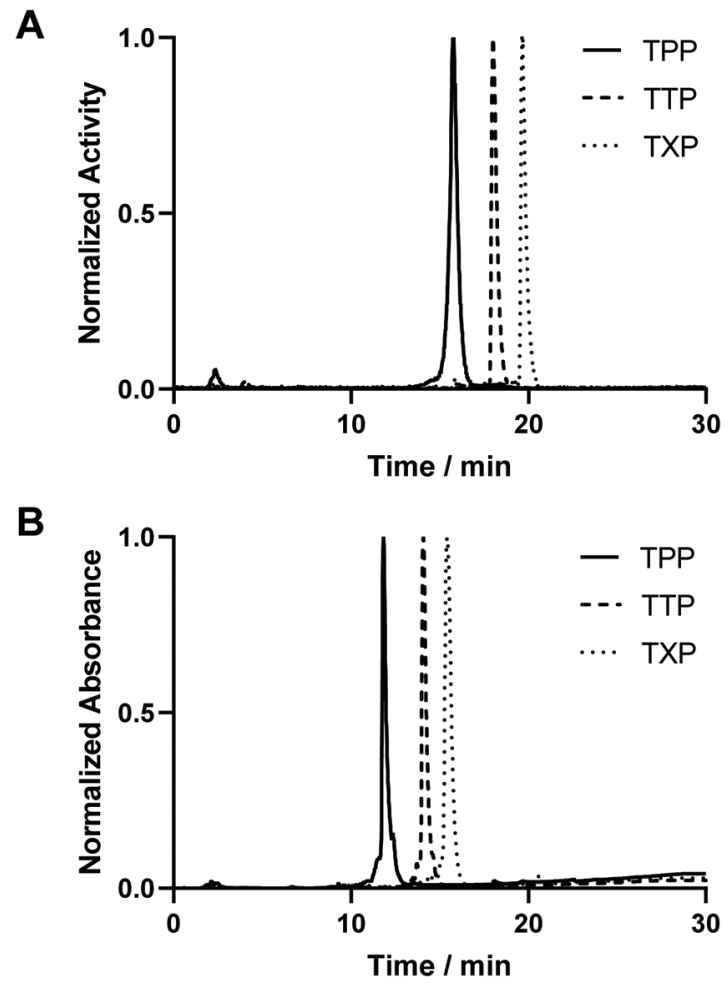

Fig. 4 (A) RadioHPLC traces of the three $\left[{ }^{68} \mathrm{Ga}\right] \mathrm{Ga}-(\mathrm{R})-\mathrm{NODAGA}-\mathrm{xy}-$ TAP complexes. (B) HPLC traces of the three respective (R)-NODAGA$x y$-TAP proligands (eluent gradient: $5 \%$ B for $5 \mathrm{~min}$; 5-95\% for $20 \mathrm{~min}$;

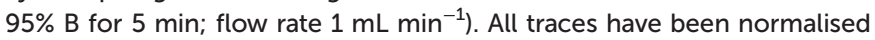
such that the maximum activity/absorbance measured for each compound is equal to 1 .

ventional 'shake-flask' method. The $\log D_{7.4}$ values, illustrated in Fig. 5, were determined to be $-2.43 \pm 0.07,-1.00 \pm 0.14$ and $-0.37 \pm 0.21$ for $\left[{ }^{68} \mathrm{Ga}\right]$ Ga-NODAGA-xy-TPP, TTP and TXP respectively ( $n=6$ for all compounds). Increasing the level of alkyl-functionalisation of the TAP moiety causes an increase in $\log D_{7.4}$ value. This trend was studied and shown previously, ${ }^{19,24,25}$ and was also observed for the $\left[{ }^{68} \mathbf{G a}\right] \mathbf{G a} 4$ compounds. The $\log D_{7.4}$ values for $\left[{ }^{68} \mathbf{G a}\right] \mathbf{G a 4}$ compounds are greater than those observed for the DO3A analogues studied previously. This provides confirmation that the removal of the unbound carboxylate arm decreases hydrophilic interactions and improves the overall lipophilicity of the $\left[{ }^{68} \mathbf{G a}\right] \mathrm{Ga} 4 \mathrm{com}$ plexes. An important characteristic exhibited by these complexes is that a small change, such as the addition of three methyl groups to the TPP group, has such a significant effect (1.4 unit difference) on the $\log D_{7.4}$ values, even when attached to the hydrophilic NODAGA macrocyclic ring. This effect was also observed upon the addition of three more methyl groups to the TTP group, resulting in a 0.6 unit difference between the TTP and TXP-functionalised compounds. As with other ${ }^{68} \mathrm{Ga}$-labelled lipophilic cations studied previously, the $\log D_{7.4}$ values of the compounds are low when compared to the 'goldstandard' SPECT-based lipophilic cation, $\left[{ }^{99 \mathrm{~m}} \mathrm{Tc}\right] \mathrm{Tc}-$ sestaMIBI, which has a $\log D_{7.4}$ value of $1.29 .^{19,24,25,34}$ However, since 


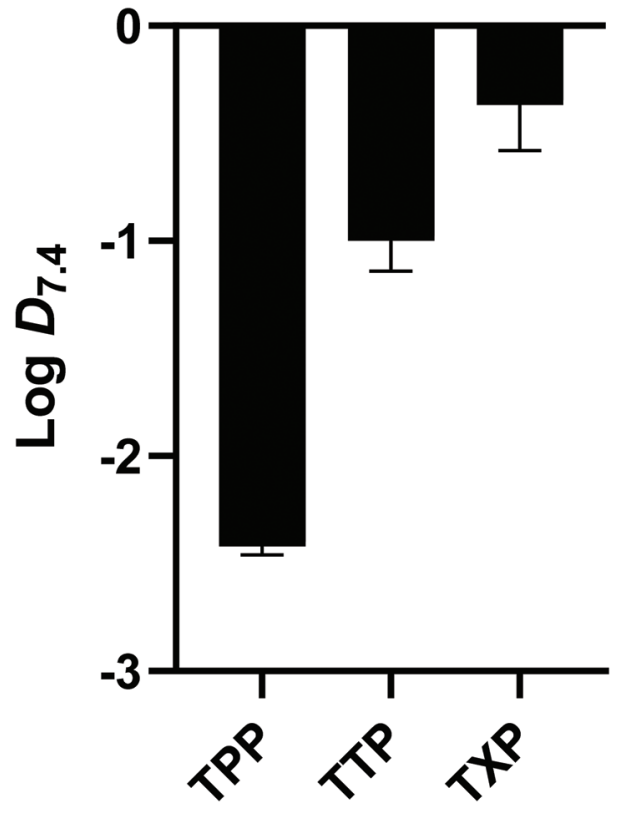

Fig. $5 \log D_{7.4}$ values obtained of the three $\left[{ }^{68} G a\right] G a-N O D A G A-x y-T A P$ compounds. Data are mean \pm SD $(n=6)$.

there is precedent of lipophilic cations with $\operatorname{low} \log D_{7.4}$ values crossing lipid bilayer membranes, we decided to perform an ex vivo assessment of the candidate radiotracer. ${ }^{15,35}$

Ex vivo quantification of $\left[{ }^{68} \mathrm{Ga}\right] \mathrm{Ga}$-NODAGA-xy-TXP myocardial uptake using the langendorff isolated perfused heart model

In order to determine whether the tracer exhibited $\Delta \Psi_{\mathrm{m}}$-dependent mitochondrial uptake, we employed the Langendorff isolated perfused heart model. This ex vivo model allows accurate and reproducible interventions on intact beating cardiac tissue which would otherwise be lethal to an animal in vivo, whilst also maintaining a high degree of in vivo relevance. Crucially for these experiments it also allows coronary perfusion (and hence radiotracer delivery) to be maintained constant, allowing the separation of the respective effects of $\Delta \Psi_{\mathrm{m}}$ and perfusion on radiotracer retention, whilst also simplifying pharmacokinetic modelling. ${ }^{28}$

To determine the dependence of cardiac radiotracer uptake and retention on $\Delta \Psi_{\mathrm{m}}$, cardiac uptake and washout curves were obtained during a control baseline period, and then during the infusion of $600 \mathrm{nM}$ carbonyl cyanide $m$-chlorophenyl hydrazone (CCCP), ${ }^{36}$ which we have previously shown to completely depolarise $\Delta \Psi_{\mathrm{m}}$, validated using the clinical SPECT radiopharmaceutical $\left[{ }^{99 \mathrm{~m}} \mathrm{Tc}\right] \mathrm{Tc}$-sestaMIBI (Fig. 1). ${ }^{8,24,25}$ We confirm this in Fig. 6A, where under baseline conditions, 25.4 $\pm 1.92 \%$ of an injected $\left[{ }^{99 \mathrm{~m}} \mathrm{Tc}\right] \mathrm{Tc}$-sestaMIBI bolus is retained in the heart 15 minutes post-injection when the mitochondria are polarised, while $0.00 \pm 0.53 \%$ is retained when the mitochondria are depolarised by $600 \mathrm{nM} \mathrm{CCCP}(n=3)$.

The myocardial uptake and retention of $\left[{ }^{68} \mathrm{Ga}\right] \mathrm{Ga} 4 \mathrm{c}$ was assessed, since this complex displayed the highest lipophilicity of the three compounds synthesised. Data from the isolated
A

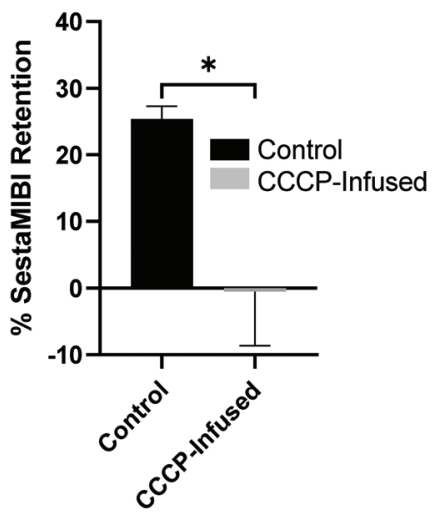

B

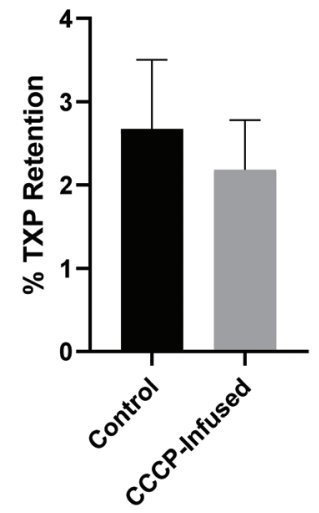

Fig. 6 (A) and (B) Cardiac retention values obtained using the isolated perfused heart model and two-injection protocol 15 minutes post-injection for $\left[{ }^{99 m} \mathrm{Tc}\right] \mathrm{Tc}-\mathrm{sestaMIBI}$ and $\left[{ }^{68} \mathrm{Ga}\right] \mathrm{Ga}-(\mathrm{R})-\mathrm{NODAGA}-\mathrm{xy}-\mathrm{TXP}$ respectively. Control data were obtained from the injection before CCCP infusion, whilst CCCP data was obtained during $600 \mathrm{nM} \mathrm{CCCP}$ infusion. Data for $\left[{ }^{99 m} \mathrm{Tc}\right] \mathrm{Tc}$-sestaMIBI are mean $\pm \mathrm{SD}(n=3)$ * ${ }^{*} P<$ 0.05 , data for $\left[{ }^{68} \mathrm{Ga}\right] \mathrm{Ga}-(\mathrm{R})-\mathrm{NODAGA}-\mathrm{xy}-\mathrm{TXP}$ are mean $\pm \mathrm{SD}(n=3)$.

heart characterisation of $\left[{ }^{68} \mathbf{G a}\right] \mathbf{G a} \mathbf{G a}$ are summarised in Fig. $6 \mathrm{~B}, 2.67 \pm 0.83 \%$ of injected dose was retained in the heart 15 minutes post-injection when cardiac mitochondria are polarised, and upon $600 \mathrm{nM}$ CCCP infusion, retention of $\left[{ }^{68} \mathrm{Ga}\right] \mathrm{Ga4c}$ was not significantly diminished in depolarised cardiac mitochondria, falling to $2.19 \pm 0.60 \%$. This lower cardiac uptake compared $\left[{ }^{99 \mathrm{~m}} \mathrm{Tc}\right] \mathrm{Tc}$-sestaMIBI is likely due to the lower lipophilicity of $\left[{ }^{68} \mathbf{G a}\right] \mathbf{G a 4 c}$ hindering passage through the lipid bilayer membrane. As a result of its increased lipophilicity, $\left[{ }^{68} \mathrm{Ga}\right] \mathrm{Ga} 4 \mathrm{c}$ does demonstrate a near three-fold increase in uptake and retention in healthy cardiac mitochondria compared to DO3A analogues studied previously. However, in depolarised cardiac mitochondria, both $\left[{ }^{68} \mathbf{G a}\right] \mathrm{Ga4c}$ and its DO3A derivative exhibited no statistically significant difference in retention compared to in healthy cardiac mitochondria. It is also possible that while net positive charge and gross lipophilicity might make the tracers more amenable to crossing cell membranes and being retained within the mitochondria than previous $\left[{ }^{68} \mathrm{Ga}\right] \mathrm{Ga}$-chelates we have investigated, the distribution of positive charges across the surface area of the complex is uneven, such that there may be a polarity within the molecule which hinders its capacity to enter the cell; it is possible that while the lipophilic "head" of the molecule may penetrate cell membranes, the cationic "tail" cannot. This polarity effect is further supported by the retention of previous DO2A analogues, which demonstrated the importance of charge distribution in terms of $\Delta \Psi_{\mathrm{m}}$-dependent retention. Based on initial analysis of molecular electrostatic potential (MEP) mapping of the DFT optimised structures of $[\mathrm{Ga}(4 \mathrm{c})]^{+}$and its DO2A counterpart, [Ga(DO2A(-xyTXP) $\left.)_{2}\right]^{3+}$ shown in Fig. S50, $\uparrow$ a more symmetrical charge distribution was observed for the DO2A analogue along with a greater distribution of positive charge across the entire mole- 
cule compared to $[\mathbf{G a}(\mathbf{4 c})]^{+}$. A more substantial and symmetrical positive charge distribution would result in greater uptake and retention polarised mitochondria, which was observed for the previous DO2A tracer, and resulted in a significant difference in retention when no membrane potential is present compared to $\left[{ }^{68} \mathbf{G a}\right] \mathrm{Ga} 4 \mathbf{c}$. $\left[{ }^{68} \mathrm{Ga}\right] \mathrm{Ga4c}$ may not exhibit superior $\Delta \Psi_{\mathrm{m}}$-dependent uptake and retention in cardiac cells compared to previous $\left[{ }^{68} \mathrm{Ga}\right] \mathrm{Ga}$-cationic species, nevertheless, this work does expand our understanding of the structure/activity relationship for refining our synthetic strategy, providing a basis for further functionalisation to improve these characteristics.

\section{Conclusions}

We have synthesised a series of TAP-functionalised NODAGA chelates for gallium-68 labelling, with a view to synthesising lipophilic and cationic radiotracers. This work represents an entirely modular and effective synthetic strategy, being the basis for synthesising a range of optimal cationic and lipophilic gallium-68 radiotracers with tuneable lipophilicity. These compounds demonstrate rapid radiolabelling with gallium-68 at room temperature, with high radiochemical yields. Cardiac uptake and retention of the most lipophilic radiotracer of this series was assessed using the Langendorff isolated perfused heart model. The results of this work show optimised radiolabelling kinetics compared to the previous gallium-68 tracer families studied in our group, however the $\log D_{7.4}$ values and cationic charge distribution over the molecules surface-area need to be improved. Nevertheless, the results emphasise and encourage the development of future gallium-68-based lipophilic cations to report on mitochondrial function.

\section{Experimental procedures}

\section{Materials and instrumentation}

Commercially available reagent grade solvents and chemicals were used without further purification. All gas mixtures were purchased from BOC Industrial Gases. Anhydrous solvents were acquired from solvent towers within the department and stored over $3 \AA$ A molecular sieves. ${ }^{1} \mathrm{H},{ }^{13} \mathrm{C}\left\{{ }^{1} \mathrm{H}\right\},{ }^{31} \mathrm{P}\left\{{ }^{1} \mathrm{H}\right\}$, COSY, HSQC, HMBC NMR spectra were recorded on a Bruker AVIII 400 spectrometer. Chemical shifts are reported in ppm and referenced to residual protonated impurities in the solvent for NMR spectra. High Resolution Electrospray Mass Spectrometry was carried out by Dr Lisa Haigh of the mass spectrometry service at Imperial College, or independently on an Aglient 6200 TOF LC-MS instrument. Flash chromatography used silica gel (60 ̊ pore size). Where specified, automated flash chromatography was performed using a Biotage Isolera Four unit and $10 \mathrm{~g}, 25 \mathrm{~g}, 50 \mathrm{~g}$ or $100 \mathrm{~g}$ SNAP KP-Sil/Sfar duo cartridge. HPLC was performed on an Agilent 1200 Series Liquid Chromatograph with UV and LabLogic Flow-Count detector with a sodium-iodide probe (B-FC-3200). Mobile phase A con- tained $\mathrm{H}_{2} \mathrm{O}$ with $0.1 \%$ TFA, and mobile phase B contained MeCN with $0.1 \%$ TFA. Analytical reverse-phase HPLC was conducted using a ZORBAX Eclipse XDB-C18 column $(4.6 \times$ $150 \mathrm{~mm}, 5 \mu \mathrm{m}$ ) and UV spectroscopic detection at $250 \mathrm{~nm}$. Gallium-68 was eluted as $\left[{ }^{68} \mathrm{Ga}\right] \mathrm{GaCl}_{3}$ from an Eckert and Ziegler gallium-68 generator using a $0.1 \mathrm{M}$ solution of hydrochloric acid.

\section{Synthesis}

TAP-functionalised xylyl bromides (1a-c) were synthesised as previously reported. ${ }^{24}(R)-4$-(4,7-Bis(2-(tert-butoxy)-2-oxoethyl)1,4,7-triazacyclononan-1-yl)-5-(tert-butoxy)-5-oxopentanoic acid $\left(\operatorname{NODAGA}\left({ }^{t} \mathrm{Bu}\right)_{3}\right)$ was synthesised according to a previously reported literature procedure by Eisenwiener $e t$ al. $^{32}$

\section{General procedure 1: synthesis of $\mathrm{NH}_{2}$-xy-TAP compounds (2)}

To a solution of 1 (1 equiv.) in EtOH $(150 \mathrm{~mL})$, aqueous $\mathrm{NH}_{3}$ $(28 \%$ wt., $40 \mathrm{~mL})$ was added, and the resulting mixture was stirred at $\mathrm{rt}$ for $48 \mathrm{~h}$. Solvent was removed under reduced pressure, before the residue was purified by reverse-phase flash chromatography (C-18 $\mathrm{SiO}_{2}, 0-100 \% \mathrm{~B}$ in A) to yield the desired product.

(4-(Aminomethyl)benzyl)triphenylphosphonium bromide (2a). Following general procedure 1, the title compound was prepared from 1a $(1.50 \mathrm{~g}, 2.85 \mathrm{mmol})$ as a white solid $(0.68 \mathrm{~g}$, $1.47 \mathrm{mmol}, 52 \%) .{ }^{1} \mathrm{H}-\mathrm{NMR}$ (400 MHz, MeOD) $\delta_{\mathrm{H}}(\mathrm{ppm}): 7.90$ $(3 \mathrm{H}, \mathrm{m}, p-\mathrm{Ph}), 7.73(6 \mathrm{H}, \mathrm{m}, m-\mathrm{Ph}), 7.66\left(6 \mathrm{H}, \mathrm{dd},{ }^{3} J_{\mathrm{HP}}=12.6\right.$, $\left.{ }^{3} J_{\mathrm{HH}}=7.7 \mathrm{~Hz}, o-\mathrm{Ph}\right), 7.35\left(2 \mathrm{H}, \mathrm{d},{ }^{3} J_{\mathrm{HH}}=8.0 \mathrm{~Hz}, \mathrm{C}_{6} \mathrm{H}_{4}\right), 7.09$ $\left(2 \mathrm{H}, \mathrm{dd},{ }^{3} J_{\mathrm{HH}}=8.3,{ }^{4} J_{\mathrm{HH}}=2.5 \mathrm{~Hz}, \mathrm{C}_{6} \mathrm{H}_{4}\right), 4.97\left(2 \mathrm{H}, \mathrm{d},{ }^{2} J_{\mathrm{HP}}=\right.$ $\left.15.3 \mathrm{~Hz}, \mathrm{CH}_{2} \mathrm{P}\right), 4.10\left(2 \mathrm{H}, \mathrm{s}, \mathrm{CH}_{2} \mathrm{NH}_{2}\right) \cdot{ }^{13} \mathrm{C}\left\{{ }^{1} \mathrm{H}\right\}-\mathrm{NMR}(101 \mathrm{MHz}$, MeOD) $\delta_{\mathrm{C}}(\mathrm{ppm}): 136.5(p-\mathrm{Ph}), 135.4\left(\mathrm{~d},{ }^{2} J_{\mathrm{CP}}=9.6 \mathrm{~Hz}, o-\mathrm{Ph}\right)$, $132.9\left(\mathrm{~d},{ }^{2} J_{\mathrm{CP}}=5.6 \mathrm{~Hz}, \mathrm{C}_{6} \mathrm{H}_{4}\right), 131.4\left(\mathrm{~d},{ }^{3} J_{\mathrm{CP}}=12.9 \mathrm{~Hz}, m-\mathrm{Ph}\right)$, $130.7\left(\mathrm{C}_{6} \mathrm{H}_{4}\right), 129.9\left(\mathrm{~d},{ }^{2} J_{\mathrm{CP}}=9.3 \mathrm{~Hz}, \mathrm{C}_{6} \mathrm{H}_{4}\right), 118.9\left(\mathrm{~d},{ }^{1} J_{\mathrm{CP}}=\right.$ $85.9 \mathrm{~Hz}, \mathrm{i}-\mathrm{Ph}), 43.6\left(\mathrm{CH}_{2} \mathrm{NH}_{2}\right), 30.3\left(\mathrm{~d},{ }^{1} J_{\mathrm{CP}}=48.4 \mathrm{~Hz}, \mathrm{CH}_{2} \mathrm{P}\right)$. ${ }^{31} \mathrm{P}\left\{{ }^{1} \mathrm{H}\right\}$-NMR (162 MHz, MeOD) $\delta_{\mathrm{P}}(\mathrm{ppm}):$ 22.9. HRMS (ES-TOF + ): $m / z$ calcd for $\mathrm{C}_{26} \mathrm{H}_{25} \mathrm{NP}\left([\mathrm{M}-\mathrm{Br}]^{+}\right) 382.1725$. Found: 382.1723 .

(4-(Aminomethyl)benzyl)tri(4-methylphenyl)phosphonium bromide (2b). Following general procedure 1, the title compound was prepared from $\mathbf{1 b}(1.50 \mathrm{~g}, 2.64 \mathrm{mmol})$ as a white solid (0.63 g, $1.25 \mathrm{mmol}, 47 \%) .{ }^{1} \mathrm{H}-\mathrm{NMR}(400 \mathrm{MHz}, \mathrm{MeOD}) \delta_{\mathrm{H}}$ (ppm): $7.56\left(6 \mathrm{H}, \mathrm{dd},{ }^{3} \mathrm{~J}_{\mathrm{HH}}=8.5,{ }^{4} \mathrm{~J}_{\mathrm{HH}}=4.1 \mathrm{~Hz}, m-\mathrm{Ar}\right), 7.51(6 \mathrm{H}$, $\left.\mathrm{d},{ }^{3} J_{\mathrm{HH}}=8.0 \mathrm{~Hz}, o-\mathrm{Ar}\right), 7.40\left(2 \mathrm{H}, \mathrm{d},{ }^{3} J_{\mathrm{HH}}=7.7 \mathrm{~Hz}, \mathrm{C}_{6} \underline{\mathrm{H}}_{4}\right), 7.12$ $\left(2 \mathrm{H}, \mathrm{dd},{ }^{3} J_{\mathrm{HH}}=8.1,{ }^{4} J_{\mathrm{HH}}=2.6 \mathrm{~Hz}, \mathrm{C}_{6} \underline{\mathrm{H}}_{4}\right), 4.92\left(2 \mathrm{H}, \overline{\mathrm{d}},{ }^{2} J_{\mathrm{HP}}=\right.$ $\left.15.1 \mathrm{~Hz}, \mathrm{CH}_{2} \mathrm{P}\right), 4.13\left(2 \mathrm{H}, \mathrm{s}, \mathrm{CH}_{2} \mathrm{NH}_{2}\right), 2.51\left(9 \mathrm{H}, \mathrm{s}, \mathrm{Ar}-\mathrm{CH}_{3}\right) .{ }^{13} \mathrm{C}$ $\left\{{ }^{1} \mathrm{H}\right\}$-NMR $(101 \mathrm{MHz}, \mathrm{MeOD}) \bar{\delta}_{\mathrm{C}}(\mathrm{ppm}): 148.0(p-\mathrm{Ar}), 135.3(\mathrm{~d}$, $\left.{ }^{2} J_{\mathrm{CP}}=9.8 \mathrm{~Hz}, o-\mathrm{Ar}\right), 135.1\left(\underline{\mathrm{C}}_{6} \mathrm{H}_{4}\right), 132.9\left(\mathrm{~d},{ }^{3} J_{\mathrm{CP}}=5.6 \mathrm{~Hz}, \underline{\mathrm{C}}_{6} \mathrm{H}_{4}\right)$, $132.0\left(\mathrm{~d},{ }^{3} J_{\mathrm{CP}}=12.9 \mathrm{~Hz}, m-\mathrm{Ar}\right), 130.7\left(\underline{\mathrm{C}}_{6} \mathrm{H}_{4}\right), 130.3\left(\mathrm{~d},{ }^{2} J_{\mathrm{CP}}=8.1\right.$ $\left.\mathrm{Hz}_{6} \mathrm{H}_{4}\right), 115.8\left(\mathrm{~d},{ }^{1} J_{\mathrm{CP}}=85.3 \mathrm{~Hz}, \mathrm{i}-\mathrm{Ar}\right), 43.7\left(\mathrm{CH}_{2} \mathrm{NH}_{2}\right), 30.7$ $\left(\mathrm{d},{ }^{1} J_{\mathrm{CP}}=49.6 \mathrm{~Hz}, \quad \mathrm{CH}_{2} \mathrm{P}\right), 21.8\left(\mathrm{Ar}-\mathrm{CH}_{3}\right) \cdot{ }^{31} \mathrm{P}\left\{{ }^{1} \mathrm{H}\right\}-\mathrm{NMR}$ (162 MHz, MeOD) $\delta_{\mathrm{P}}$ (ppm): 22.1. HRMS (ES-TOF+): $\mathrm{m} / z$ calcd for $\mathrm{C}_{29} \mathrm{H}_{31} \mathrm{NP}\left([\mathrm{M}-\mathrm{Br}]^{+}\right)$424.2194. Found: 424.2193.

(4-(Aminomethyl)benzyl)tri(3,5-dimethylphenyl)phosphonium bromide (2c). Following general procedure 1, the title compound was prepared from $1 \mathrm{c}(1.99 \mathrm{~g}, 3.26 \mathrm{mmol})$ as a white solid (0.55 g, $1.01 \mathrm{mmol}, 31 \%) .{ }^{1} \mathrm{H}-\mathrm{NMR}(400 \mathrm{MHz}, \mathrm{MeOD}) \delta_{\mathrm{H}}$ 
(ppm): $7.54\left(3 \mathrm{H}, \mathrm{s}, p\right.$-Ar), $7.41\left(2 \mathrm{H}, \mathrm{d},{ }^{3} J_{\mathrm{HH}}=7.8 \mathrm{~Hz}, \mathrm{C}_{6} \mathrm{H}_{4}\right)$, $7.23\left(6 \mathrm{H}, \mathrm{d},{ }^{3} J_{\mathrm{HH}}=13.0 \mathrm{~Hz}, o-\mathrm{Ar}\right), 7.09\left(2 \mathrm{H}, \mathrm{dd},{ }^{3} J_{\mathrm{HH}}=8.1,{ }^{4} J_{\mathrm{HH}}\right.$ $\left.=2.7 \mathrm{~Hz}, \mathrm{C}_{6} \underline{\mathrm{H}}_{4}\right), 4.90\left(2 \mathrm{H}, \mathrm{dd},{ }^{2} J_{\mathrm{HP}}=15.1,{ }^{3} J_{\mathrm{HH}}=5.9 \mathrm{~Hz}, \mathrm{CH}_{2} \mathrm{P}\right)$, $4.13\left(2 \mathrm{H}, \mathrm{s}, \mathrm{C}_{2} \mathrm{NH}_{2}\right), 2.38\left(18 \mathrm{H}, \mathrm{s}, \mathrm{Ar}-\mathrm{CH}_{3}\right) \cdot{ }^{13} \mathrm{C}\left\{{ }^{1} \mathrm{H}\right\}-\mathrm{NMR}$ (101 MHz, MeOD) $\delta_{\mathrm{C}}(\mathrm{ppm}): 141.7\left(\mathrm{~d},{ }^{3} J_{\mathrm{CP}}=13.9 \mathrm{~Hz}, m-\mathrm{Ar}\right)$, 137.9 (p-Ar), $135.1\left(\underline{\mathrm{C}}_{6} \mathrm{H}_{4}\right), 133.1\left(\mathrm{~d},{ }^{3} J_{\mathrm{CP}}=5.7 \mathrm{~Hz}, \underline{\mathrm{C}}_{6} \mathrm{H}_{4}\right), 132.6$ $\left(\mathrm{d},{ }^{2} J_{\mathrm{CP}}=10.0 \mathrm{~Hz}, o-\mathrm{Ar}\right), 130.5\left(\underline{\mathrm{C}}_{6} \mathrm{H}_{4}\right), 118.9\left(\mathrm{~d},{ }^{1} J_{\mathrm{CP}}=85.1 \mathrm{~Hz}\right.$, i-Ar), $43.7\left(\underline{\mathrm{CH}}_{2} \mathrm{NH}_{2}\right), 30.5$ (d, $\left.{ }^{1} \bar{J}_{\mathrm{CP}}=49.3 \mathrm{~Hz}, \underline{\mathrm{CH}}_{2} \mathrm{P}\right), 21.3$ (Ar$\mathrm{CH}_{3}$ ). ${ }^{31} \mathrm{P}\left\{{ }^{1} \mathrm{H}\right\}-N M R(162 \mathrm{MHz}, \mathrm{MeOD}) \delta_{\mathrm{P}}$ (ppm): 22.2. HRMS (ES-TOF+): $m / z$ calcd for $\mathrm{C}_{32} \mathrm{H}_{37} \mathrm{NP}\left([\mathrm{M}-\mathrm{Br}]^{+}\right)$466.2664. Found: 466.2646 .

General procedure 2: synthesis of tert-butyl protected (R)NODAGA-xy-TAP compounds (3)

This methodology was a modification of the procedure described by Schirrmacher et al. ${ }^{33}$ (R)-NODAGA $\left({ }^{t} \mathrm{Bu}\right)_{3}$ (1 equiv.) and 2 (1.2 equiv.) were dissolved in mixture of $\mathrm{H}_{2} \mathrm{O}$ and MeCN $(1: 1)$. DCC (1.1 equiv.) was dissolved in pyridine and added dropwise to the mixture before being stirred at $\mathrm{rt}$ for $48 \mathrm{~h}$. The solvent was removed under reduced pressure, before the crude residue was dissolved in $\mathrm{MeCN}(8.0 \mathrm{~mL})$ and the urea byproduct was removed by filtration. The solvent was removed under reduced pressure and the residue was purified by reverse-phase flash chromatography $\left(\mathrm{C}-18 \mathrm{SiO}_{2}, 0-100 \% \mathrm{~B}\right.$ in A) to yield the desired product.

(R)-(4-((4-(4,7-Bis(2-(tert-butoxy)-2-oxoethyl)-1,4,7-triazonan1-yl)-5-(tert-butoxy)-5-oxopentanamido)methyl)benzyl) triphenylphosphonium bromide (3a). Following general procedure 2 , the title compound was prepared from (R)-NODAGA $\left({ }^{t} \mathrm{Bu}\right)_{3}$ (0.10 g, $0.19 \mathrm{mmol}), 2 \mathrm{a}(0.10 \mathrm{~g}, 0.21 \mathrm{mmol}), \mathrm{H}_{2} \mathrm{O}: \mathrm{MeCN}(1: 1$, $9.0 \mathrm{~mL}), \mathrm{DCC}(0.04 \mathrm{~g}, 0.20 \mathrm{mmol})$ and pyridine $(1.15 \mathrm{~mL})$ as a pale yellow solid (0.07 g, $0.07 \mathrm{mmol}, 39 \%) .{ }^{1} \mathrm{H}-\mathrm{NMR}(400 \mathrm{MHz}$, MeOD) $\delta_{\mathrm{H}}(\mathrm{ppm}): 7.88\left(3 \mathrm{H}, \mathrm{t},{ }^{3} J_{\mathrm{HH}}=7.6 \mathrm{~Hz}, p-\mathrm{Ph}\right), 7.70(6 \mathrm{H}, \mathrm{m}$, $m-\mathrm{Ph}), 7.62\left(6 \mathrm{H}, \mathrm{dd},{ }^{3} J_{\mathrm{HP}}=12.7,{ }^{3} J_{\mathrm{HH}}=8.0 \mathrm{~Hz}, o-\mathrm{Ph}\right), 7.14(2 \mathrm{H}$, $\left.\mathrm{d},{ }^{3} J_{\mathrm{HH}}=7.7 \mathrm{~Hz}, \mathrm{C}_{6} \underline{\mathrm{H}}_{4}\right), 6.95\left(2 \mathrm{H}, \mathrm{dd},{ }^{3} J_{\mathrm{HH}}=7.9,{ }^{4} J_{\mathrm{HH}}=2.6 \mathrm{~Hz}\right.$, $\left.\mathrm{C}_{6} \underline{\mathrm{H}}_{4}\right), 4.88\left(2 \mathrm{H}, \mathrm{d},{ }^{2} \mathrm{~J}_{\mathrm{HP}}=15.1 \mathrm{~Hz}, \mathrm{CH}_{2} \mathrm{P}\right), 4.31\left(2 \mathrm{H}, \mathrm{s}, \mathrm{CH}_{2} \mathrm{NH}\right)$, $3.51\left(5 \mathrm{H}, \mathrm{m}, \mathrm{C} \underline{\mathrm{HN}} / \mathrm{C}_{2} \mathrm{COO}^{t} \mathrm{Bu}\right), 3.09(12 \mathrm{H}, \mathrm{m}$, macrocycle $\underline{\mathrm{H}})$, $2.41\left(2 \mathrm{H}, \mathrm{t},{ }^{3} \mathrm{~J}_{\mathrm{HH}}=7.8 \mathrm{~Hz}, \mathrm{CH}_{2} \mathrm{CONH}\right), 2.02\left(2 \mathrm{H}, \mathrm{m}, \mathrm{NCHC}_{2}\right)$, $1.48\left(27 \mathrm{H}, \mathrm{m}, \mathrm{COOC}\left(\mathrm{CH}_{3}\right)_{3}\right) \cdot{ }^{13} \mathrm{C}\left\{{ }^{1} \mathrm{H}\right\}-\mathrm{NMR}(101 \mathrm{MHz}, \mathrm{MeOD})$ $\delta_{\mathrm{C}}(\mathrm{ppm}): 175.0(\underline{\mathrm{CONH}}), 173.1\left(\underline{\mathrm{COO}}{ }^{t} \mathrm{Bu}\right), 141.2\left(\underline{\mathrm{C}}_{6} \mathrm{H}_{4}\right), 136.5$ $(p-\mathrm{Ph}), 135.3\left(\mathrm{~d},{ }^{2} J_{\mathrm{CP}}=9.7 \mathrm{~Hz}, o-\mathrm{Ph}\right), 132.3\left(\mathrm{~d},{ }^{2} J_{\mathrm{CP}}=5.7 \mathrm{~Hz}\right.$, $\left.\underline{\mathrm{C}}_{6} \mathrm{H}_{4}\right), 131.4\left(\mathrm{~d},{ }^{3} J_{\mathrm{CP}}=12.4 \mathrm{~Hz}, m-\mathrm{Ph}\right), 129.1\left(\underline{\mathrm{C}}_{6} \mathrm{H}_{4}\right), 127.4$ $\left(\underline{\mathrm{C}}_{6} \mathrm{H}_{4}\right), 119.1\left(\mathrm{~d},{ }^{1} J_{\mathrm{CP}}=86.5 \mathrm{~Hz}, \mathrm{i}-\mathrm{Ph}\right), 84.4,83.5,83.3$ $\left(\underline{\mathrm{C}}\left(\mathrm{CH}_{3}\right)_{3}\right), 64.9(\underline{\mathrm{CHNH}}), 56.4\left(\underline{\mathrm{CH}}_{2} \mathrm{COO}^{t} \mathrm{Bu}\right), 52.8,51.5,46.9$, 45.9 (macrocycle $\underline{\mathrm{C}}), 43.5\left(\underline{\mathrm{CH}}_{2} \mathrm{NH}\right), 33.8\left(\underline{\mathrm{CH}}_{2} \mathrm{CONH}\right), 30.4(\mathrm{~d}$, $\left.{ }^{1} J_{\mathrm{CP}}=46.9 \mathrm{~Hz}, \underline{\mathrm{CH}}_{2} \mathrm{P}\right), 28.4\left(\mathrm{C}\left(\underline{\mathrm{CH}}_{3}\right)_{3}\right), 27.1\left(\mathrm{NCHCH}_{2}\right) .{ }^{31} \mathrm{P}\left\{{ }^{1} \mathrm{H}\right\}$ NMR (162 MHz, MeOD) $\delta_{\mathrm{P}}$ (ppm): 22.4. HRMS (ES-TOF+): $\mathrm{m} / z$ calcd for $\mathrm{C}_{53} \mathrm{H}_{72} \mathrm{~N}_{4} \mathrm{O}_{7} \mathrm{P}\left([\mathrm{M}-\mathrm{Br}]^{+}\right)$907.5139. Found: 907.5150.

(R)-(4-((4-(4,7-Bis(2-(tert-butoxy)-2-oxoethyl)-1,4,7-triazonan1-yl)-5-(tert-butoxy)-5-oxopentanamido)methyl)benzyl)tri(4-methylphenyl)phosphonium bromide (3b). Following general procedure 2 , the title compound was prepared from (R)-NODAGA $\left({ }^{t} \mathrm{Bu}\right)_{3}$ (0.10 g, $0.19 \mathrm{mmol}), 2 \mathrm{~b}(0.11 \mathrm{~g}, 0.22 \mathrm{mmol}), \mathrm{H}_{2} \mathrm{O}: \mathrm{MeCN}(1: 1$, $9.0 \mathrm{~mL})$, DCC $(0.04 \mathrm{~g}, 0.20 \mathrm{mmol})$ and pyridine $(1.25 \mathrm{~mL})$ as a pale yellow solid (0.09 g, $0.09 \mathrm{mmol}, 46 \%) .{ }^{1} \mathrm{H}-\mathrm{NMR}(400 \mathrm{MHz}$, MeOD) $\delta_{\mathrm{H}}(\mathrm{ppm}): 7.52\left(6 \mathrm{H}, \mathrm{dd},{ }^{3} J_{\mathrm{HH}}=8.1,{ }^{4} J_{\mathrm{HH}}=3.4 \mathrm{~Hz}, m-\mathrm{Ar}\right)$, $7.45\left(6 \mathrm{H}, \mathrm{dd},{ }^{3} J_{\mathrm{HP}}=12.3,{ }^{3} J_{\mathrm{HH}}=8.1 \mathrm{~Hz}, o-\mathrm{Ar}\right), 7.15\left(2 \mathrm{H}, \mathrm{d},{ }^{3} J_{\mathrm{HH}}\right.$ $\left.=7.0 \mathrm{~Hz}, \mathrm{C}_{6} \underline{\mathrm{H}}_{4}\right), 6.95\left(2 \mathrm{H}, \mathrm{dd},{ }^{3} J_{\mathrm{HH}}=7.8,{ }^{4} J_{\mathrm{HH}}=2.7 \mathrm{~Hz}, \mathrm{C}_{6} \underline{\mathrm{H}}_{4}\right)$, $4.77\left(2 \mathrm{H}, \mathrm{d},{ }^{2} J_{\mathrm{HP}}=14.9 \mathrm{~Hz}, \mathrm{CH}_{2} \mathrm{P}\right), 4.33\left(2 \mathrm{H}, \mathrm{s}, \mathrm{CH}_{2} \mathrm{NH}\right), 3.58$ $\left(5 \mathrm{H}, \mathrm{m}, \mathrm{C}_{2} \mathrm{COO}^{t} \mathrm{Bu} / \mathrm{C} \underline{\mathrm{HN}}\right), 3.04(12 \mathrm{H}, \mathrm{m}$, macrocycle $\underline{\mathrm{H}}), 2.50$ $\left(9 \mathrm{H}, \mathrm{s}, \mathrm{Ar}-\underline{\mathrm{C}}_{3}\right), 2.40\left(2 \mathrm{H}, \mathrm{m}, \mathrm{CH}_{2} \mathrm{CONH}\right), 2.03(2 \mathrm{H}, \mathrm{m}$, $\left.\mathrm{NCHCH}_{2}\right), \quad 1.49 \quad\left(27 \mathrm{H}, \quad \mathrm{m}, \quad \mathrm{COOC}\left(\mathrm{C}_{3}\right)_{3}\right) . \quad{ }^{13} \mathrm{C}\left\{{ }^{1} \mathrm{H}\right\}-\mathrm{NMR}$ (101 MHz, MeOD) $\delta_{\mathrm{C}}(\mathrm{ppm}): 175.0(\underline{\mathrm{CONH}}), 173.1$ (OO $\left.^{t} \mathrm{Bu}\right)$, $171.2\left(\underline{\mathrm{COO}}{ }^{t} \mathrm{Bu}\right), 168.5\left(\underline{\mathrm{COO}}{ }^{t} \mathrm{Bu}\right), 148.0(p-\mathrm{Ar}), 141.0\left(\underline{\mathrm{C}}_{6} \mathrm{H}_{4}\right)$, $135.2\left(\mathrm{~d},{ }^{2} J_{\mathrm{CP}}=9.7 \mathrm{~Hz}, o-\mathrm{Ar}\right), 132.3\left(\mathrm{~d},{ }^{2} J_{\mathrm{CP}}=6.1 \mathrm{~Hz}, \underline{\mathrm{C}}_{6} \mathrm{H}_{4}\right)$, $131.9\left(\mathrm{~d},{ }^{3} J_{\mathrm{CP}}=12.9 \mathrm{~Hz}, m-\mathrm{Ar}\right), 129.0\left(\underline{\mathrm{C}}_{6} \mathrm{H}_{4}\right), 127.8\left(\underline{\mathrm{C}}_{6} \mathrm{H}_{4}\right)$, $115.9\left(\mathrm{~d},{ }^{1} J_{\mathrm{CP}}=89.5 \mathrm{~Hz}, \mathrm{i}-\mathrm{Ar}\right), 84.4,83.4,83.2\left(\mathrm{COOC}\left(\mathrm{CH}_{3}\right)_{3}\right)$, $64.9(\underline{\mathrm{CHN}}), 56.4\left(\underline{\mathrm{CH}}_{2} \mathrm{COO}^{t} \mathrm{Bu}\right), 52.9,51.3,46.9,46.0$ (macrocycle $\underline{\mathrm{C}}), 43.5\left(\underline{\mathrm{CH}}_{2} \mathrm{NH}\right), 33.8\left(\underline{\mathrm{CH}}_{2} \mathrm{CONH}\right), 30.7\left(\mathrm{~d},{ }^{1} J_{\mathrm{CP}}=48.1\right.$ $\left.\mathrm{Hz}, \underline{\mathrm{CH}}_{2} \mathrm{P}\right), 28.5,28.4,28.2\left(\mathrm{COOC}\left(\underline{\mathrm{CH}}_{3}\right)_{3}\right), 27.2\left(\mathrm{NCHCH}_{2}\right), 21.8$ $\left(\mathrm{Ar}-\underline{\mathrm{C}}_{3}\right) .{ }^{31} \mathrm{P}\left\{{ }^{1} \mathrm{H}\right\}-\mathrm{NMR}(162 \mathrm{MHz}, \mathrm{MeOD}) \delta_{\mathrm{P}}(\mathrm{ppm}): 21.8$. HRMS (ES-TOF+): $m / z$ calcd for $\mathrm{C}_{56} \mathrm{H}_{78} \mathrm{~N}_{4} \mathrm{O}_{7} \mathrm{P}\left([\mathrm{M}-\mathrm{Br}]^{+}\right)$ 949.5603. Found: 949.5592 .

(R)-(4-((4-(4,7-Bis(2-(tert-butoxy)-2-oxoethyl)-1,4,7-triazonan1-yl)-5-(tert-butoxy)-5-oxopentanamido)methyl)benzyl)tri(3,5methylphenyl)phosphonium bromide (3c). Following general procedure 2 , the title compound was prepared from (R)$\operatorname{NODAGA}\left({ }^{t} \mathrm{Bu}\right)_{3}(0.10 \mathrm{~g}, 0.19 \mathrm{mmol}), 2 \mathrm{c}(0.12 \mathrm{~g}, 0.22 \mathrm{mmol})$, $\mathrm{H}_{2} \mathrm{O}: \mathrm{MeCN}(1: 1,9.0 \mathrm{~mL})$, DCC $(0.04 \mathrm{~g}, 0.20 \mathrm{mmol})$ and pyridine $(1.25 \mathrm{~mL})$ as a pale yellow solid $(0.09 \mathrm{~g}, 0.09 \mathrm{mmol}, 46 \%)$. ${ }^{1} \mathrm{H}-\mathrm{NMR}(400 \mathrm{MHz}, \mathrm{MeOD}) \delta_{\mathrm{H}}(\mathrm{ppm}): 7.51$ (3H, m, p-Ar), 7.15 $\left(8 \mathrm{H}, \mathrm{m}, o-\mathrm{Ar} / \mathrm{C}_{6} \underline{\mathrm{H}}_{4}\right), 6.91\left(2 \mathrm{H}, \mathrm{dd},{ }^{3} \mathrm{~J}_{\mathrm{HH}}=8.2,{ }^{4} J_{\mathrm{HH}}=2.5 \mathrm{~Hz}\right.$, $\left.\mathrm{C}_{6} \underline{\mathrm{H}}_{4}\right), 4.75\left(2 \mathrm{H}, \mathrm{d},{ }^{2} J_{\mathrm{HP}}=14.8 \mathrm{~Hz}, \mathrm{CH}_{2} \mathrm{P}\right), 4.34\left(2 \mathrm{H}, \mathrm{s}, \mathrm{CH}_{2} \mathrm{NH}\right)$, $3.79\left(4 \mathrm{H}, \mathrm{m}, \mathrm{CH}_{2} \mathrm{COO}^{t} \mathrm{Bu}\right), 3.54\left(1 \mathrm{H}, \mathrm{t},{ }^{3} J_{\mathrm{HH}}=7.3 \mathrm{~Hz},{ }_{\mathrm{C}} \mathrm{HN}\right)$, $3.11(12 \mathrm{H}, \mathrm{m}$, macrocycle $\underline{\mathrm{H}}), 2.48\left(2 \mathrm{H}, \mathrm{m}, \mathrm{CH}_{2} \mathrm{CONH}\right), 2.35$ $\left(18 \mathrm{H}, \mathrm{s}, \mathrm{Ar}-\mathrm{CH}_{3}\right), 2.02\left(2 \mathrm{H}, \mathrm{m}, \mathrm{NCHCH}_{2}\right), 1.49(27 \mathrm{H}, \mathrm{s}, \mathrm{COOC}$ $\left.\left(\mathrm{CH}_{3}\right)_{3}\right) .{ }^{13} \mathrm{C}\left\{{ }^{1} \mathrm{H}\right\}-\mathrm{NMR}(101 \mathrm{MHz}, \mathrm{MeOD}) \delta_{\mathrm{C}}(\mathrm{ppm}): 175.0$ $(\underline{\mathrm{CONH}}) 173.0\left(\underline{\mathrm{COO}}^{t} \mathrm{Bu}\right), 141.7\left(\mathrm{~d},{ }^{3} J_{\mathrm{CP}}=13.1 \mathrm{~Hz}, m-\mathrm{Ar}\right), 141.1$ $\left(\overline{\mathrm{d}},{ }^{5} J_{\mathrm{CP}}=3.9 \mathrm{~Hz}, \underline{\mathrm{C}}_{6} \mathrm{H}_{4}\right), 137.8\left(\mathrm{~d},{ }^{4} J_{\mathrm{CP}}=3.3 \mathrm{~Hz}, p-\mathrm{Ar}\right), 132.6(\mathrm{~d}$, $\left.{ }^{2} J_{\mathrm{CP}}=9.7 \mathrm{~Hz}, o-\mathrm{Ar}\right), 132.4\left(\mathrm{~d},{ }^{3} J_{\mathrm{CP}}=5.6 \mathrm{~Hz}, \underline{\mathrm{C}}_{6} \mathrm{H}_{4}\right), 128.9\left(\mathrm{~d},{ }^{4} J_{\mathrm{CP}}\right.$ $\left.=3.4 \mathrm{~Hz}, \underline{\mathrm{C}}_{6} \mathrm{H}_{4}\right), 128.0\left(\mathrm{~d},{ }^{2} J_{\mathrm{CP}}=8.6 \mathrm{~Hz}, \underline{\mathrm{C}}_{6} \mathrm{H}_{4}\right), 119.1\left(\mathrm{~d},{ }^{1} J_{\mathrm{CP}}=\right.$

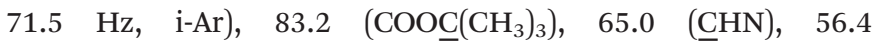
$\left(\underline{\mathrm{CH}}_{2} \mathrm{COO}^{t} \mathrm{Bu}\right.$ ), 52.8, 51.4, 46.9, 46.0 (macrocycle $\underline{\mathrm{C}}$ ), 43.5 $\left(\underline{\mathrm{CH}}_{2} \mathrm{NH}\right), 33.8\left(\underline{\mathrm{CH}}_{2} \mathrm{CONH}\right), 30.5\left(\mathrm{~d},{ }^{1} J_{\mathrm{CP}}=48.3 \mathrm{~Hz}, \underline{\mathrm{CH}}_{2} \mathrm{P}\right)$, 28.5, 28.4, $28.3\left(\mathrm{COOC}\left(\underline{\mathrm{CH}}_{3}\right)_{3}\right), 27.1\left(\mathrm{NCHCH}_{2}\right), 21.3\left(\mathrm{Ar}^{-} \underline{\mathrm{CH}}_{3}\right)$. ${ }^{31} \mathrm{P}\left\{{ }^{1} \mathrm{H}\right\}-N M R \quad(162 \mathrm{MHz}, \mathrm{MeOD}) \delta_{\mathrm{P}}$ (ppm): 22.2. HRMS (ES-TOF+): $m / z$ calcd for $\mathrm{C}_{59} \mathrm{H}_{84} \mathrm{~N}_{4} \mathrm{O}_{7} \mathrm{P}\left([\mathrm{M}-\mathrm{Br}]^{+}\right) 991.6078$. Found: 991.6077.

General procedure 3: deprotection of tert-butyl protected (R)NODAGA-xy-TAP compounds using trifluoroacetic acid (4)

Compounds 3a-c were dissolved in trifluoroacetic acid (reaction mixture concentration $0.1 \mathrm{~g} \mathrm{~mL}^{-1}$ ) and stirred at rt under an $\mathrm{N}_{2}$ atmosphere for $48 \mathrm{~h}$. The acid was removed under reduced pressure, before the residue was purified by reversephase flash chromatography (C-18 $\mathrm{SiO}_{2}, 0-100 \% \mathrm{~B}$ in A) to yield the desired product.

(R)-NODAGA-xy-TPP trifluoroacetate (4a). Following general procedure 3 , the title compound was prepared from $3 \mathbf{a}(0.18 \mathrm{~g}$, $0.18 \mathrm{mmol})$ and trifluoroacetic acid $(1.80 \mathrm{~mL})$ as a white solid (0.10 g, $0.12 \mathrm{mmol}, 67 \%) .{ }^{1} \mathrm{H}-\mathrm{NMR}$ (400 MHz, MeOD) $\delta_{\mathrm{H}}$ (ppm): $7.89\left(3 \mathrm{H}, \mathrm{t},{ }^{3} J_{\mathrm{HH}}=7.5 \mathrm{~Hz}, p-\mathrm{Ph}\right), 7.72\left(6 \mathrm{H}, \mathrm{dt},{ }^{3} J_{\mathrm{HH}}=\right.$ 
$\left.7.7,{ }^{4} J_{\mathrm{HH}}=3.5 \mathrm{~Hz}, m-\mathrm{Ph}\right), 7.63\left(6 \mathrm{H}, \mathrm{dd},{ }^{3} J_{\mathrm{HP}}=12.6,{ }^{3} J_{\mathrm{HH}}=7.7\right.$ $\mathrm{Hz}, o-\mathrm{Ph}), 7.16\left(2 \mathrm{H}, \mathrm{d},{ }^{3} J_{\mathrm{HH}}=7.7 \mathrm{~Hz}, \mathrm{C}_{6} \underline{\mathrm{H}}_{4}\right), 6.95\left(2 \mathrm{H}, \mathrm{dd},{ }^{3} J_{\mathrm{HH}}\right.$ $\left.=7.9,{ }^{4} J_{\mathrm{HH}}=2.7 \mathrm{~Hz}, \mathrm{C}_{6} \underline{\mathrm{H}}_{4}\right), 4.88\left(2 \mathrm{H}, \mathrm{d},{ }^{2} J_{\mathrm{HP}}=14.9 \mathrm{~Hz}, \mathrm{CH}_{2} \mathrm{P}\right)$, $4.33\left(2 \mathrm{H}, \mathrm{s}, \mathrm{CH}_{2} \mathrm{NH}\right), 3.97\left(4 \mathrm{H}, \mathrm{m}, \mathrm{CH}_{2} \mathrm{COOH}\right), 3.61\left(1 \mathrm{H}, \mathrm{t},{ }^{3} J_{\mathrm{HH}}\right.$ $=7.1 \mathrm{~Hz}, \underline{\mathrm{CHN}}), 3.11(12 \mathrm{H}, \mathrm{m}$, macrocycle $\underline{\mathrm{H}}), 2.47(2 \mathrm{H}, \mathrm{m}$, $\left.\mathrm{CH}_{2} \mathrm{CONH}\right), 2.09\left(2 \mathrm{H}, \mathrm{m}, \mathrm{NCHCH}_{2}\right) .{ }^{13} \mathrm{C}\left\{{ }^{1} \mathrm{H}\right\}-\mathrm{NMR}(101 \mathrm{MHz}$, MeOD) $\delta_{\mathrm{C}}(\mathrm{ppm}): 175.1(\underline{\mathrm{CONH}}), 175.0(\underline{\mathrm{COOH}}), 141.2\left(\mathrm{~d},{ }^{5} J_{\mathrm{CP}}\right.$ $\left.=4.2 \mathrm{~Hz}, \underline{\mathrm{C}}_{6} \mathrm{H}_{4}\right), 136.5\left(\mathrm{~d},{ }^{4} J_{\mathrm{CP}}=3.2 \mathrm{~Hz}, p-\mathrm{Ph}\right), 135.3\left(\mathrm{~d},{ }^{2} J_{\mathrm{CP}}=\right.$ $9.7 \mathrm{~Hz}, o-\mathrm{Ph}), 132.3\left(\mathrm{~d},{ }^{2} J_{\mathrm{CP}}=5.5 \mathrm{~Hz}, \underline{\mathrm{C}}_{6} \mathrm{H}_{4}\right), 131.3\left(\mathrm{~d},{ }^{3} J_{\mathrm{CP}}=\right.$ $12.8 \mathrm{~Hz}, m-\mathrm{Ph}), 129.1\left(\mathrm{~d},{ }^{4} J_{\mathrm{CP}}=3.5 \mathrm{~Hz}, \underline{\mathrm{C}}_{6} \mathrm{H}_{4}\right), 127.4\left(\mathrm{~d},{ }^{3} J_{\mathrm{CP}}=\right.$ $\left.8.8 \mathrm{~Hz}, \underline{\mathrm{C}}_{6} \mathrm{H}_{4}\right), 119.1$ (d, $\left.{ }^{1} J_{\mathrm{CP}}=86.5 \mathrm{~Hz}, \mathrm{i}-\mathrm{Ph}\right), 64.3(\underline{\mathrm{CHN}}), 55.8$ $\left(\underline{\mathrm{CH}}_{2} \mathrm{COOH}\right), 52.1,47.2$ (macrocycle $\left.\underline{\mathrm{C}}\right), 43.5\left(\underline{\mathrm{CH}}_{2} \mathrm{NH}\right), 33.6$ $\left(\underline{\mathrm{CH}}_{2} \mathrm{CONH}\right), 30.4$ (d, $\left.{ }^{1} J_{\mathrm{CP}}=48.4 \mathrm{~Hz}, \underline{\mathrm{CH}}_{2} \mathrm{P}\right), 26.6\left(\mathrm{NCHCH}_{2}\right)$. ${ }^{31} \mathrm{P}\left\{{ }^{1} \mathrm{H}\right\}-\mathrm{NMR}(162 \mathrm{MHz}, \mathrm{MeOD}) \delta_{\mathrm{P}}(\mathrm{ppm}): 22.6 .{ }^{19} \mathrm{~F}\left\{{ }^{1} \mathrm{H}\right\}-\mathrm{NMR}$ (377 MHz, MeOD) $\delta_{\mathrm{F}}(\mathrm{ppm}):-77.1$. HRMS (ES-TOF+): $\mathrm{m} / \mathrm{z}$ calcd for $\mathrm{C}_{41} \mathrm{H}_{48} \mathrm{~N}_{4} \mathrm{O}_{7} \mathrm{P}\left(\left[\mathrm{M}-\mathrm{CF}_{3} \mathrm{CO}_{2}\right]^{+}\right)$739.3261. Found: 739.3265 .

(R)-NODAGA-xy-TTP trifluoroacetate (4b). Following general procedure 3 , the title compound was prepared from $\mathbf{3 b}(0.09 \mathrm{~g}$, $0.09 \mathrm{mmol})$ and trifluoroacetic acid $(0.9 \mathrm{~mL})$ as a white solid (0.05 g, $0.06 \mathrm{mmol}, 61 \%) .{ }^{1} \mathrm{H}-\mathrm{NMR}$ (400 MHz, MeOD) $\delta_{\mathrm{H}}$ (ppm): $7.52\left(6 \mathrm{H}, \mathrm{dd},{ }^{3} J_{\mathrm{HH}}=8.3,{ }^{4} J_{\mathrm{HH}}=3.4 \mathrm{~Hz}, m-\mathrm{Ar}\right), 7.45(6 \mathrm{H}$, $\left.\mathrm{dd},{ }^{3} J_{\mathrm{HP}}=12.2,{ }^{3} J_{\mathrm{HH}}=8.1 \mathrm{~Hz}, o-\mathrm{Ar}\right), 7.16\left(2 \mathrm{H}, \mathrm{d},{ }^{3} J_{\mathrm{HH}}=7.9 \mathrm{~Hz}\right.$, $\left.\mathrm{C}_{6} \underline{\mathrm{H}}_{4}\right), 6.94\left(2 \mathrm{H}, \mathrm{dd},{ }^{3} J_{\mathrm{HH}}=8.1,{ }^{4} J_{\mathrm{HH}}=2.7 \mathrm{~Hz}, \mathrm{C}_{6} \underline{\mathrm{H}}_{4}\right), 4.75$ $\left(2 \overline{\mathrm{H}}, \mathrm{d},{ }^{2} J_{\mathrm{HP}}=14.9 \mathrm{~Hz}, \mathrm{CH}_{2} \mathrm{P}\right), 4.33\left(2 \mathrm{H}, \mathrm{s}, \mathrm{CH}_{2} \mathrm{NH}\right), 3.88(5 \mathrm{H}$, $\left.\mathrm{m}, \mathrm{CH}_{2} \mathrm{COOH} / \mathrm{CHN}\right), 3.10(12 \mathrm{H}, \mathrm{m}$, macrocycle $\mathrm{H}), 2.50(9 \mathrm{H}$, $\left.\mathrm{s}, \mathrm{Ar}-\overline{\mathrm{CH}}_{3}\right), 2.46\left(2 \mathrm{H}, \mathrm{m}, \mathrm{CH}_{2} \mathrm{CONH}\right), 2.08\left(2 \mathrm{H}, \mathrm{m}, \mathrm{NCHCH}_{2}\right)$. ${ }^{13} \mathrm{C}\left\{{ }^{1} \mathrm{H}\right\}-\mathrm{NMR}(101 \mathrm{MHz}, \mathrm{MeOD}) \delta_{\mathrm{C}}(\mathrm{ppm}): 175.1$ (ㅁNH/ COOH), 148.1 (p-Ar), $141.1\left(\underline{\mathrm{C}}_{6} \mathrm{H}_{4}\right), 135.2\left(\mathrm{~d},{ }^{2} J_{\mathrm{CP}}=9.9 \mathrm{~Hz}\right.$, $o$-Ar), $132.2\left(\mathrm{~d},{ }^{3} J_{\mathrm{CP}}=5.2 \mathrm{~Hz}, \underline{\mathrm{C}}_{6} \mathrm{H}_{4}\right), 131.9\left(\mathrm{~d},{ }^{3} J_{\mathrm{CP}}=12.4 \mathrm{~Hz}\right.$, $m$-Ar), $129.0\left(\underline{\mathrm{C}}_{6} \mathrm{H}_{4}\right), 127.8\left(\mathrm{~d},{ }^{2} J_{\mathrm{CP}}=8.7 \mathrm{~Hz}, \underline{\mathrm{C}}_{6} \mathrm{H}_{4}\right), 115.9$ (d, $\left.{ }^{1} J_{\mathrm{CP}}=88.5 \mathrm{~Hz}, \mathrm{i}-\mathrm{Ar}\right), 64.3(\underline{\mathrm{CHN}}), 55.8\left(\underline{\mathrm{CH}}_{2} \mathrm{COOH}\right), 52.0,47.0$ (macrocycle $\mathrm{C}), 43.6\left(\mathrm{CH}_{2} \mathrm{NH}\right), 33.6\left(\mathrm{CH}_{2} \mathrm{CONH}\right), 30.8\left(\mathrm{~d},{ }^{1} J_{\mathrm{CP}}\right.$ $\left.=48.8 \mathrm{~Hz}, \underline{\mathrm{CH}}_{2} \mathrm{P}\right), 26.6\left(\mathrm{NCHCH}_{2}\right), 21.8\left(\mathrm{Ar}^{-} \underline{\mathrm{CH}}_{3}\right) .{ }^{31} \mathrm{P}\left\{{ }^{1} \mathrm{H}\right\}-$ NMR (162 MHz, MeOD) $\delta_{\mathrm{P}}(\mathrm{ppm}): 21.8$. HRMS (ES-TOF+): $m / z$ calcd for $\mathrm{C}_{44} \mathrm{H}_{54} \mathrm{~N}_{4} \mathrm{O}_{7} \mathrm{P}\left(\left[\mathrm{M}-\mathrm{CF}_{3} \mathrm{CO}_{2}\right]^{+}\right)$781.3730. Found: 781.3740 .

(R)-NODAGA-xy-TXP trifluoroacetate (4c). Following general procedure 3 , the title compound was prepared from $3 \mathbf{c}(0.10 \mathrm{~g}$, $0.09 \mathrm{mmol})$ and trifluoroacetic acid $(1.0 \mathrm{~mL})$ as a white solid (0.06 g, $0.07 \mathrm{mmol}, 76 \%$ ). ${ }^{1} \mathrm{H}-\mathrm{NMR}$ (400 MHz, MeOD) $\delta_{\mathrm{H}}$ (ppm): $7.52(3 \mathrm{H}, \mathrm{m}, p-\mathrm{Ar}), 7.15\left(8 \mathrm{H}, \mathrm{m}, o-\mathrm{Ar} / \mathrm{C}_{6} \underline{\mathrm{H}}_{4}\right), 6.91(2 \mathrm{H}$, $\left.\mathrm{dd},{ }^{3} J_{\mathrm{HH}}=8.2,{ }^{4} J_{\mathrm{HH}}=2.5 \mathrm{~Hz}, \mathrm{C}_{6} \underline{\mathrm{H}}_{4}\right), 4.74\left(2 \mathrm{H}, \mathrm{d},{ }^{2} J_{\mathrm{HP}}=14.8 \mathrm{~Hz}\right.$, $\left.\mathrm{CH}_{2} \mathrm{P}\right), 4.33\left(2 \mathrm{H}, \mathrm{s}, \mathrm{CH}_{2} \mathrm{NH}\right), 3.84\left(4 \mathrm{H}, \mathrm{m}, \mathrm{CH}_{2} \mathrm{COO}^{t} \mathrm{Bu}\right), 3.60$ $\left(1 \overline{\mathrm{H}}, \mathrm{t},{ }^{3} \mathrm{~J}_{\mathrm{HH}}=7.2 \mathrm{~Hz}, \overline{\mathrm{C}}_{\underline{\mathrm{HN}}}\right), 3.15(12 \mathrm{H}, \mathrm{m}$, macrocycle $\underline{\mathrm{H}}), 2.46$ $\left(2 \mathrm{H}, \mathrm{m}, \mathrm{CH}_{2} \mathrm{CONH}\right), 2.35\left(18 \mathrm{H}, \mathrm{s}, \mathrm{Ar}_{-} \underline{\mathrm{C}}_{3}\right), 2.06(2 \mathrm{H}, \mathrm{m}$, $\left.\mathrm{NCHCH}_{2}\right) \cdot{ }^{13} \mathrm{C}\left\{{ }^{1} \mathrm{H}\right\}-\mathrm{NMR}(101 \mathrm{MHz}, \mathrm{MeOD}) \delta_{\mathrm{C}}(\mathrm{ppm}): 175.1$ $(\underline{\mathrm{CONH}} / \underline{\mathrm{COOH}}), 141.7$ (d, $\left.{ }^{3} J_{\mathrm{CP}}=13.0 \mathrm{~Hz}, m-\mathrm{Ar}\right), 141.2\left(\underline{\mathrm{C}}_{6} \mathrm{H}_{4}\right)$, 137.9 (p-Ar), $132.6\left(\mathrm{~d},{ }^{2} J_{\mathrm{CP}}=9.7 \mathrm{~Hz}, o-\mathrm{Ar}\right), 132.4\left(\underline{\mathrm{C}}_{6} \mathrm{H}_{4}\right), 128.9$ $\left(\underline{\mathrm{C}}_{6} \mathrm{H}_{4}\right), 128.0\left(\underline{\mathrm{C}}_{6} \mathrm{H}_{4}\right), 119.0\left(\mathrm{~d},{ }^{1} J_{\mathrm{CP}}=85.0 \mathrm{~Hz}, \mathrm{i}-\mathrm{Ar}\right), 64.2(\underline{\mathrm{CHN}})$, $55.8\left(\mathrm{CH}_{2} \mathrm{COOH}\right.$ ), 52.2, 51.6, 47.3, 46.5 (macrocycle $\mathrm{C}$ ), 43.5 $\left(\underline{\mathrm{CH}}_{2} \mathrm{NH}\right), 33.6\left(\underline{\mathrm{CH}}_{2} \mathrm{CONH}\right), 30.6\left(\mathrm{~d},{ }^{1} J_{\mathrm{CP}}=48.0 \mathrm{~Hz}, \underline{\mathrm{CH}}_{2} \mathrm{P}\right), 26.6$ $\left(\mathrm{NCHCH}_{2}\right), 21.3\left(\mathrm{Ar}^{-\mathrm{CH}_{3}}\right) .{ }^{31} \mathrm{P}\left\{{ }^{1} \mathrm{H}\right\}-\mathrm{NMR}(162 \mathrm{MHz}, \mathrm{MeOD}) \delta_{\mathrm{P}}$ (ppm): 22.2. ${ }^{19} \mathrm{~F}\left\{{ }^{1} \mathrm{H}\right\}-\mathrm{NMR}(377 \mathrm{MHz}, \mathrm{MeOD}) \delta_{\mathrm{F}}$ (ppm): -77.4. HRMS (ES-TOF+): $m / z$ calcd for $\mathrm{C}_{47} \mathrm{H}_{60} \mathrm{~N}_{4} \mathrm{O}_{7} \mathrm{P}\left(\left[\mathrm{M}-\mathrm{CF}_{3} \mathrm{CO}_{2}\right]^{+}\right)$ 823.4200. Found: 823.4175.
General procedure 4: complexation of (R)-NODAGA-xy-TAP compounds with ${ }^{\text {nat }} \mathrm{Ga}^{3+}\left(\left[{ }^{\text {nat }} \mathrm{Ga}\right] \mathrm{Ga} 4\right)$

To a solution of 4 ( 1 equiv.) in NaOAc buffer $(3.60 \mathrm{M}, 5.00 \mathrm{~mL}$, pH 5.00), $\mathrm{Ga}\left(\mathrm{NO}_{3}\right)_{3} \cdot x \mathrm{H}_{2} \mathrm{O}$ (1.5 equiv.) was added, and the resulting suspension was stirred at $\mathrm{rt}$ for $15 \mathrm{~min}$. The solvent was removed under reduced pressure, before the residue was purified by reverse-phase flash chromatography (C-18 $\mathrm{SiO}_{2}$, $0-100 \% \mathrm{~B}$ in A) to yield the desired product.

\section{$\left[{ }^{\text {nat }} \mathrm{Ga}\right] \mathrm{Ga}-(\mathrm{R})-\mathrm{NODAGA}-\mathrm{xy}-\mathrm{TPP}$ trifluoroacetate ([ $\left.\left.{ }^{\text {nat }} \mathrm{Ga}\right] \mathrm{Ga} 4 \mathrm{a}\right)$}

Following general procedure 4 , the title compound was prepared from $4 \mathrm{a}(0.03 \mathrm{~g}, 0.04 \mathrm{mmol})$ and $\mathrm{Ga}\left(\mathrm{NO}_{3}\right)_{3} \cdot x \mathrm{H}_{2} \mathrm{O}(0.01 \mathrm{~g}$, $0.05 \mathrm{mmol})$ as a white solid $(0.03 \mathrm{~g}, 0.03 \mathrm{mmol}, 83 \%) .{ }^{1} \mathrm{H}-\mathrm{NMR}$ (400 MHz, MeOD) $\delta_{\mathrm{H}}(\mathrm{ppm}): 7.88(3 \mathrm{H}, \mathrm{m}, p-\mathrm{Ph}), 7.71(6 \mathrm{H}, \mathrm{td}$, $\left.{ }^{3} J_{\mathrm{HH}}=7.7,{ }^{4} J_{\mathrm{HH}}=3.5 \mathrm{~Hz}, m-\mathrm{Ph}\right), 7.63\left(6 \mathrm{H}, \mathrm{dd},{ }^{3} J_{\mathrm{HP}}=12.5,{ }^{3} J_{\mathrm{HH}}\right.$ $=7.7 \mathrm{~Hz}, o-\mathrm{Ph}), 7.14\left(2 \mathrm{H}, \mathrm{d},{ }^{3} J_{\mathrm{HH}}=7.5 \mathrm{~Hz}, \mathrm{C}_{6} \underline{\mathrm{H}}_{4}\right), 6.99(2 \mathrm{H}, \mathrm{m}$, $\left.\mathrm{C}_{6} \underline{\mathrm{H}}_{4}\right), 4.88\left(2 \mathrm{H}, \mathrm{m}, \mathrm{C}_{2} \mathrm{P}\right), 4.29\left(2 \mathrm{H}, \mathrm{m}, \underline{\mathrm{C}}_{2} \mathrm{NH}\right), 3.67(5 \mathrm{H}, \mathrm{m}$, $\left.\mathrm{C}_{2} \mathrm{COOGa} / \mathrm{C} \underline{\mathrm{HN}}\right), 3.49(4 \mathrm{H}, \mathrm{m}$, macrocycle $\underline{\mathrm{H}}), 3.13(8 \mathrm{H}, \mathrm{m}$, macrocycle $\underline{\mathrm{H}}), 2.63\left(2 \mathrm{H}, \mathrm{m}, \mathrm{CH}_{2} \mathrm{CONH}\right), 2.20(2 \mathrm{H}, \mathrm{m}$, $\left.\mathrm{NCHCH}_{2}\right) .{ }^{13} \mathrm{C}\left\{{ }^{1} \mathrm{H}\right\}-\mathrm{NMR}(101 \mathrm{MHz}, \mathrm{MeOD}) \delta_{\mathrm{C}}(\mathrm{ppm}): 175.7$

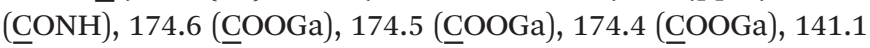
$\left(\underline{\mathrm{C}}_{6} \mathrm{H}_{4}\right), 136.5(p-\mathrm{Ph}), 135.4\left(\mathrm{~d},{ }^{2} J_{\mathrm{CP}}=9.7 \mathrm{~Hz}, o-\mathrm{Ph}\right), 132.5(\mathrm{~d}$, $\left.{ }^{2} J_{\mathrm{CP}}=5.5 \mathrm{~Hz}, \underline{\mathrm{C}}_{6} \mathrm{H}_{4}\right), 131.4\left(\mathrm{~d},{ }^{3} J_{\mathrm{CP}}=12.6 \mathrm{~Hz}, m-\mathrm{Ph}\right), 129.2$ (d, $\left.{ }^{4} J_{\mathrm{CP}}=3.3 \mathrm{~Hz}, \underline{\mathrm{C}}_{6} \mathrm{H}_{4}\right), 127.4\left(\underline{\mathrm{C}}_{6} \mathrm{H}_{4}\right), 119.1\left(\mathrm{~d},{ }^{1} J_{\mathrm{CP}}=86.1 \mathrm{~Hz}\right.$, i-Ph), 68.5 ( $\underline{\mathrm{CHN}}), 63.43\left(\mathrm{CH}_{2} \mathrm{COOGa}\right), 54.8,54.5,54.1,53.8$ (macrocycle $\underline{\mathrm{C}}), 43.5\left(\underline{\mathrm{CH}}_{2} \mathrm{NH}\right), 34.04\left(\underline{\mathrm{CH}}_{2} \mathrm{CONH}\right), 30.4\left(\mathrm{~d},{ }^{1} J_{\mathrm{CP}}\right.$ $\left.=48.4 \mathrm{~Hz}, \underline{\mathrm{CH}}_{2} \mathrm{P}\right), 23.7\left(\mathrm{NCHCH}_{2}\right) .{ }^{31} \mathrm{P}\left\{{ }^{1} \mathrm{H}\right\}-\mathrm{NMR}(162 \mathrm{MHz}$, $\mathrm{MeOD}) \delta_{\mathrm{P}}(\mathrm{ppm}): 22.6$.

HRMS (ES-TOF+): $m / z$ calcd for $\mathrm{C}_{41} \mathrm{H}_{46} \mathrm{~N}_{4} \mathrm{O}_{7} \mathrm{P}^{69} \mathrm{Ga}([\mathrm{M}-$ $\left.\mathrm{CF}_{3} \mathrm{CO}_{2}\right]^{+}$) 806.2360. Found: 806.2341.

\section{$\left[{ }^{\text {nat }} \mathrm{Ga}\right] \mathrm{Ga}-(\mathrm{R})-\mathrm{NODAGA}-\mathrm{xy}-\mathrm{TTP}$ trifluoroacetate ([$\left.\left.{ }^{\text {nat }} \mathrm{Ga}\right] \mathrm{Ga} 4 \mathrm{~b}\right)$}

Following general procedure 4 , the title compound was prepared from $4 \mathbf{b}(0.03 \mathrm{~g}, 0.03 \mathrm{mmol})$ and $\mathrm{Ga}\left(\mathrm{NO}_{3}\right)_{3} \cdot x \mathrm{H}_{2} \mathrm{O}(0.01 \mathrm{~g}$, $0.04 \mathrm{mmol})$ as a white solid (0.03 g, $0.03 \mathrm{mmol}, 97 \%) .{ }^{1} \mathrm{H}-\mathrm{NMR}$ (400 MHz, MeOD) $\delta_{\mathrm{H}}(\mathrm{ppm}): 7.52\left(6 \mathrm{H}, \mathrm{dd},{ }^{3} J_{\mathrm{HH}}=8.2,{ }^{4} J_{\mathrm{HH}}=\right.$ $3.4 \mathrm{~Hz}, m-\mathrm{Ar}), 7.45\left(6 \mathrm{H}, \mathrm{dd},{ }^{3} J_{\mathrm{HP}}=12.2,{ }^{3} J_{\mathrm{HH}}=8.1 \mathrm{~Hz}, o-\mathrm{Ar}\right)$, $7.14\left(2 \mathrm{H}, \mathrm{d},{ }^{3} J_{\mathrm{HH}}=7.7 \mathrm{~Hz}, \mathrm{C}_{6} \underline{\mathrm{H}}_{4}\right), 6.98\left(2 \mathrm{H}, \mathrm{m}, \mathrm{C}_{6} \underline{\mathrm{H}}_{4}\right), 4.76(2 \mathrm{H}$, $\left.\mathrm{d},{ }^{2} J_{\mathrm{HP}}=14.9 \mathrm{~Hz}, \mathrm{CH}_{2} \mathrm{P}\right), 4.32\left(2 \mathrm{H}, \mathrm{m}, \mathrm{CH}_{2} \mathrm{NH}\right), 3.67(5 \mathrm{H}, \mathrm{m}$, $\left.\mathrm{CH}_{2} \mathrm{COOGa} / \mathrm{C} \underline{\mathrm{HN}}\right), 3.47(4 \mathrm{H}, \mathrm{m}$, macrocycle $\underline{\mathrm{H}}), 3.22(8 \mathrm{H}, \mathrm{m}$, macrocycle $\underline{\mathrm{H}}), 2.62$ (2H, m, $\left.\mathrm{CH}_{2} \mathrm{CONH}\right), 2.49$ (9H, s, $\left.\mathrm{Ar}-\mathrm{CH}_{3}\right)$, $2.23\left(2 \mathrm{H}, \mathrm{m}, \mathrm{NCHCH}_{2}\right) .{ }^{13} \mathrm{C}\left\{{ }^{1} \overline{\mathrm{H}}\right\}-\mathrm{NMR}(101 \mathrm{MHz}, \mathrm{MeOD}) \delta_{\mathrm{C}}$

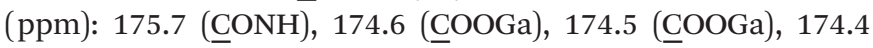
(COOGa), 148.0 (d, $\left.{ }^{4} J_{\mathrm{CP}}=3.2 \mathrm{~Hz}, p-\mathrm{Ar}\right), 141.0\left(\mathrm{~d},{ }^{4} J_{\mathrm{CP}}=4.2 \mathrm{~Hz}\right.$, $\left.\underline{\mathrm{C}}_{6} \mathrm{H}_{4}\right), 135.2\left(\mathrm{~d},{ }^{2} J_{\mathrm{CP}}=9.8 \mathrm{~Hz}, o-\mathrm{Ar}\right), 132.5\left(\mathrm{~d},{ }^{3} J_{\mathrm{CP}}=5.3 \mathrm{~Hz}\right.$, $\left.\underline{\mathrm{C}}_{6} \mathrm{H}_{4}\right), 131.9\left(\mathrm{~d},{ }^{3} J_{\mathrm{CP}}=12.9 \mathrm{~Hz}, m-\mathrm{Ar}\right), 129.1\left(\mathrm{~d},{ }^{5} J_{\mathrm{CP}}=3.3 \mathrm{~Hz}\right.$, $\left.\underline{\mathrm{C}}_{6} \mathrm{H}_{4}\right), 127.8\left(\mathrm{~d},{ }^{2} J_{\mathrm{CP}}=8.7 \mathrm{~Hz}, \underline{\mathrm{C}}_{6} \mathrm{H}_{4}\right), 115.9\left(\mathrm{~d},{ }^{1} J_{\mathrm{CP}}=89.1 \mathrm{~Hz}\right.$, i-Ar), 68.5 ( $\underline{\mathrm{CHN}}), 63.4$ ( $\left.\mathrm{CH}_{2} \mathrm{COOGa}\right), 54.8,54.5,54.1,53.8$ (macrocycle $\underline{\mathrm{C}}$ ), $43.6\left(\underline{\mathrm{CH}}_{2} \mathrm{NH}\right), 34.03\left(\underline{\mathrm{CH}}_{2} \mathrm{CONH}\right), 30.8\left(\mathrm{~d},{ }^{1} J_{\mathrm{CP}}\right.$ $\left.=48.8 \mathrm{~Hz}, \underline{\mathrm{CH}}_{2} \mathrm{P}\right), 22.9\left(\mathrm{NCHCH}_{2}\right), 21.8\left(\mathrm{Ar}^{-\mathrm{CH}_{3}}\right) .{ }^{31} \mathrm{P}\left\{{ }^{1} \mathrm{H}\right\}-\mathrm{NMR}$ (162 MHz, MeOD) $\delta_{\mathrm{P}}(\mathrm{ppm}):$ 21.8. HRMS (ES-TOF+): $\mathrm{m} / \mathrm{z}$ calcd for $\mathrm{C}_{44} \mathrm{H}_{52} \mathrm{~N}_{4} \mathrm{O}_{7} \mathrm{P}^{69} \mathrm{Ga}\left(\left[\mathrm{M}-\mathrm{CF}_{3} \mathrm{CO}_{2}\right]^{+}\right)$848.2829. Found: 848.2817 . 
$\left[{ }^{\text {nat }}\right.$ Ga] Ga-(R)-NODAGA-xy-TXP trifluoroacetate $\left(\left[{ }^{\text {nat }} \mathrm{Ga}\right] \mathrm{Ga4c}\right)$

Following general procedure 4, the title compound was prepared from $4 \mathbf{c}(0.03 \mathrm{~g}, 0.03 \mathrm{mmol})$ and $\mathrm{Ga}\left(\mathrm{NO}_{3}\right)_{3} \cdot \mathrm{xH}_{2} \mathrm{O}(0.01 \mathrm{~g}$, $0.05 \mathrm{mmol})$ as a white solid (0.03 g, $0.03 \mathrm{mmol}, 99 \%) .{ }^{1} \mathrm{H}-\mathrm{NMR}$ (400 MHz, MeOD) $\delta_{\mathrm{H}}(\mathrm{ppm}): 7.51(3 \mathrm{H}, \mathrm{m}, p-\mathrm{Ar}), 7.14(8 \mathrm{H}, \mathrm{m}$, $\left.o-\mathrm{Ar} / \mathrm{C}_{6} \underline{\mathrm{H}}_{4}\right), 6.94\left(2 \mathrm{H}, \mathrm{dd},{ }^{3} J_{\mathrm{HH}}=8.2,{ }^{4} \mathrm{~J}_{\mathrm{HH}}=2.5 \mathrm{~Hz}, \mathrm{C}_{6} \underline{\mathrm{H}}_{4}\right), 4.75$ $\left(2 \mathrm{H}, \mathrm{d},{ }^{2} J_{\mathrm{HP}}=14.7 \mathrm{~Hz}, \mathrm{C}_{2} \mathrm{P}\right), 4.33\left(2 \mathrm{H}, \mathrm{m}, \mathrm{C}_{2} \mathrm{NH}\right), 3.67(5 \mathrm{H}$, $\left.\mathrm{m}, \mathrm{C}_{2}{ }_{2} \mathrm{COOGa} / \mathrm{CHN}\right), 3.45$ (4H, m, macrocycle $\left.\underline{\mathrm{H}}\right), 3.10(8 \mathrm{H}, \mathrm{m}$, macrocycle $\underline{\mathrm{H}}), 2.58\left(2 \mathrm{H}, \mathrm{m}, \mathrm{C}_{2} \mathrm{CONH}\right), 2.35\left(18 \mathrm{H}, \mathrm{s}, \mathrm{Ar}-\mathrm{C}_{3}\right)$, $2.01\left(2 \mathrm{H}, \mathrm{m}, \mathrm{NCHCH}_{2}\right) \cdot{ }^{13} \mathrm{C}\left\{{ }^{1} \mathrm{H}\right\}-\mathrm{NMR}(101 \mathrm{MHz}, \mathrm{MeOD}) \delta_{\mathrm{C}}$

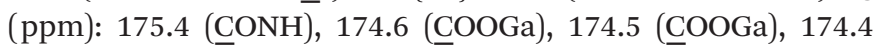
(COOGa), $141.7(m-\mathrm{Ar}), 141.6\left(\underline{\mathrm{C}}_{6} \mathrm{H}_{4}\right), 137.9(p-\mathrm{Ar}), 132.6\left(\mathrm{~d},{ }^{2} J_{\mathrm{CP}}\right.$ $=8.7 \mathrm{~Hz}, o-\mathrm{Ar}), 128.9\left(\underline{\mathrm{C}}_{6} \mathrm{H}_{4}\right), 128.0\left(\underline{\mathrm{C}}_{6} \mathrm{H}_{4}\right), 119.0\left(\mathrm{~d},{ }^{1} J_{\mathrm{CP}}=84.8\right.$ $\mathrm{Hz}, \mathrm{i}-\mathrm{Ar}$ ), $63.4(\mathrm{CHN}), 54.8$ ( $\left.\mathrm{CH}_{2} \mathrm{COOGa}\right), 54.1,53.8$ (macrocycle C), $43.5\left(\underline{\mathrm{CH}}_{2} \mathrm{NH}\right), 34.0\left(\underline{\mathrm{CH}}_{2} \mathrm{CONH}\right), 30.3\left(\mathrm{~d},{ }^{1} J_{\mathrm{CP}}=48.0 \mathrm{~Hz}\right.$, $\left.\mathrm{CH}_{2} \mathrm{P}\right), 22.8\left(\mathrm{NCHCH}_{2}\right), 21.3\left(\mathrm{Ar}^{-} \mathrm{CH}_{3}\right) .{ }^{31} \mathrm{P}\left\{{ }^{1} \mathrm{H}\right\}-\mathrm{NMR}(162 \mathrm{MHz}$, MeOD) $\delta_{\mathrm{P}}$ (ppm): 22.2. HRMS (ES-TOF+): $\mathrm{m} / \mathrm{z}$ calcd for $\mathrm{C}_{47} \mathrm{H}_{58} \mathrm{~N}_{4} \mathrm{O}_{7} \mathrm{P}^{69} \mathrm{Ga}\left(\left[\mathrm{M}-\mathrm{CF}_{3} \mathrm{CO}_{2}\right]^{+}\right)$890.3299. Found: 890.3305.

\section{Radiochemistry procedures}

General synthesis of gallium-68-radiolabelled compounds. To a solution of ligand $(100 \mu \mathrm{M})$ in NaOAc buffer $(3.60 \mathrm{M}$, $42 \mu \mathrm{L}$ ), an aliquot of $\left[{ }^{68} \mathrm{Ga}\right] \mathrm{GaCl}_{3}$ in $0.1 \mathrm{M} \mathrm{HCl}$ (approx. 50 $\mathrm{MBq}, 500 \mu \mathrm{L}$, final mixture $\mathrm{pH} 5.00$ ) was added, and the resulting mixture was heated at $25^{\circ} \mathrm{C}$ for $15 \mathrm{~min}$ to yield the desired product. Initial QC was performed using iTLC (LabLogic) and two mobile phases, $0.1 \mathrm{M}$ disodium EDTA and $2.0 \mathrm{M}$ $\mathrm{NH}_{4} \mathrm{OAc}: \mathrm{MeOH}(1: 1)$, were implemented. Initial QC was also performed using analytical HPLC (Eluent gradient: 95\% A for $5 \mathrm{~min}, 5-95 \%$ B in A for $25 \mathrm{~min}, 5 \%$ B in A for $5 \mathrm{~min}$; flow rate $1 \mathrm{~mL} \mathrm{~min}^{-1}$ ).

Determination of $\log D_{7.4}$ values. As an index for lipophilicity, octanol/phosphate buffered saline (PBS) partition coefficient $\left(\log D_{7.4}\right)$ values of the radiolabelled compounds were determined. A general methodology is as follows: aliquots of the radiolabelled compound $(5 \mu \mathrm{L}$, approx. $200 \mathrm{kBq})$ were added to vials containing a layered mixture of $n$-octanol $(500 \mu \mathrm{L})$ and PBS $(\mathrm{pH} 7.4,500 \mu \mathrm{L})$. After vortex mixing for $1 \mathrm{~min}$, the mixture was centrifuged to separate the octanol/PBS phases $\left(10^{4} \mathrm{rpm}, 2 \mathrm{~min}\right)$, before aliquots of the two phases $(100 \mu \mathrm{L})$ were taken and transferred into vials for counting. Relative amounts of test compound in each phase were determined by an automatic gamma counter. The $\log D_{7.4}$ value was reported as the mean $\pm \mathrm{SD}$ of data obtained in 6 independent experiments.

\section{Langendorff isolated heart perfusion}

Animals. Male Wistar rats (275-299 g; Envigo) were used for all experiments. Animal procedures were in accordance with the Animals (Scientific Procedures) Act, UK, 1986.

The triple- $\gamma$-detector system. We developed a system for characterizing the pharmacokinetics of radionuclide passage through an isolated perfused heart comprising of 3 orthogonally orientated lead-collimated $\mathrm{Na} / \mathrm{I} \gamma$ detectors positioned: (i) $3 \mathrm{~cm}$ downstream of a radiotracer injection port on the arterial line, $15 \mathrm{~cm}$ upstream of the heart cannula (to provide an input function); (ii) directly opposite the heart itself; and (iii) over the venous outflow line (to provide an output function). Each was connected to a modified GinaSTAR instant thin-layer chromatography system running Gina software (Raytest Ltd).

Experimental protocol. Rats were anaesthetized with sodium pentobarbital and heparin sodium $\left(200 \mathrm{mg} \mathrm{kg}^{-1}\right.$ and $200 \mathrm{IU}$ $\mathrm{kg}^{-1}$ respectively, i.p.) and their hearts were excised and cannulated in the Langendorff mode as previously described. ${ }^{29,37}$ The hearts were perfused at $14 \mathrm{~mL} \mathrm{~min}{ }^{-1}$ constant flow with modified Krebs-Henseleit buffer (mKHB) containing $\mathrm{NaCl}$ (118 mM), KCl (5.9 mM), $\mathrm{MgSO}_{4}(2.3 \mathrm{mM}), \mathrm{NaHCO}_{3}(25 \mathrm{mM})$, EDTA $(0.65 \mathrm{mM})$, glucose $(11.1 \mathrm{mM})$ and $\mathrm{CaCl}_{2}(2.5 \mathrm{mM})$. The mKHB was freshly prepared and filtered before use and was gassed with $95 \% \mathrm{O}_{2}$ and $5 \% \mathrm{CO}_{2}$ and used at $37{ }^{\circ} \mathrm{C}$. A left ventricular balloon was used to measure contractile function via a Powerlab monitoring system running LabChart (AD Instruments Ltd).

After a 10 min stabilization period, a bolus of radiotracer (1 $\mathrm{MBq}$ ) was injected into the arterial line, and the activity at the arterial, heart and venous detectors was recorded. After 15 minutes, a $6 \mu \mathrm{M}$ solution of CCCP in mKHB heated to $37^{\circ} \mathrm{C}$ was infused via the arterial line at $1.4 \mathrm{~mL} \mathrm{~min}^{-1}$, whilst the flow rate at the peristaltic pump was reduced by $10 \%$. A further $1 \mathrm{MBq}$ radiotracer bolus was administered 5 minutes after the commencement of CCCP infusion. The radiotracer retained after $15 \mathrm{~min}$ in both the healthy and CCCP-infused hearts was reported as the average of the normalized activity between 14-15 minutes after the radiotracer injection.

\section{DFT calculations}

All calculations were performed using the Gaussian 16 package (Revision C.01). ${ }^{38}$ Full geometry optimisations were performed using the $\omega$ B97X-D functional ${ }^{39}$ in aqueous solution using the polarisable continuum model (PCM) ${ }^{40}$ with the LANL2DZ basis set and effective core potentials for $\mathrm{Ga}$, and 6$311+G^{* *}$ for all other atoms. ${ }^{41}$ Frequency analysis of the optimised structures confirmed a true minimum energy structure by the absence of imaginary frequencies.

\section{Author contributions}

N. J. L. and R. S. jointly supervised the work. B. E. O. carried out the synthetic chemistry, radiochemistry and isolated heart perfusion. E. C. T. W. and F. B. performed Langendorff and triple $\gamma$-detector training and supervision and assisted with heart perfusion experiments. T. T. C. Y. performed the DFT calculations. All authors contributed to the writing and proofreading of the manuscript.

\section{Conflicts of interest}

There are no conflicts to declare. 


\section{Acknowledgements}

All experimental procedures were approved by King's College London's local Animal Care and Ethics Committee, and carried out in accordance with Home Office regulations as detailed in the Guidance on the Operation of Animals (Scientific Procedures) Act 1986.

We would like to thank the King's College London \& Imperial College London EPSRC Centre for Doctoral Training in Medical Imaging (EP/L015226/1) and the EPSRC Programme grants for Next Generation Molecular Imaging and Therapy with Radionuclides (EP/S032789/1 "MITHRAS", EP/ S019901/1 "RedOx_KCL") funding, and Imperial College London for studentship funding for B. E. O.

\section{Notes and references}

1 J. Maddahi, H. Kiat, K. F. Van Train, F. Prigent, J. Friedman, E. V. Garcia, N. Alazraki, E. G. DePuey, K. Nichols and D. S. Berman, Am. J. Cardiol., 1990, 66, E55-E62.

2 J. D. Kelly, A. M. Forster, B. Higley, C. M. Archer, F. S. Booker, L. R. Canning, K. W. Chiu, B. Edwards, H. K. Gill and M. McPartlin, J. Nucl. Med., 1993, 34, 222227.

3 M. L. Chiu, J. F. Kronauge and D. Piwnica-Worms, J. Nucl. Med., 1990, 31, 1646-1653.

4 D. Piwnica-Worms, J. F. Kronauge and M. L. Chiu, Circulation, 1990, 82, 1826-1838.

5 M. P. Murphy, Trends Biotechnol., 1997, 15, 326-330.

6 M. P. Murphy, Biochim. Biophys. Acta, Bioenerg., 2008, 1777, 1028-1031.

7 B. Kadenbach, R. Ramzan, R. Moosdorf and S. Vogt, Mitochondrion, 2011, 11, 700-706.

8 Z. M. Safee, F. Baark, E. C. T. Waters, M. Veronese, V. R. Pell, J. E. Clark, F. Mota, L. Livieratos, T. R. Eykyn, P. J. Blower and R. Southworth, Sci. Rep., 2019, 9, 216.

9 H. Fukuda, A. Syrota, P. Charbonneau, J. Vallois, M. Crouzel, C. Prenant, J. Sastre and C. Crouzel, Eur. J. Nucl. Med., 1986, 11, 478-483.

10 H. T. Ravert, I. Madar and R. F. Dannals, J. Labelled Compd. Radiopharm., 2004, 47, 469-476.

11 M. F. Ross, T. Da Ros, F. H. Blaikie, T. A. Prime, C. M. Porteous, I. I. Severina, V. P. Skulachev, H. G. Kjaergaard, R. A. J. Smith and M. P. Murphy, Biochem. J., 2006, 400, 199-208.

12 D.-Y. Kim, H.-J. Kim, K.-H. Yu and J.-J. Min, Bioorg. Med. Chem. Lett., 2012, 22, 319-322.

13 D.-Y. Kim, H.-J. Kim, K.-H. Yu and J.-J. Min, Bioconjugate Chem., 2012, 23, 431-437.

14 G. Zhao, Y.-M. Yu, T. M. Shoup, D. R. Elmaleh, A. A. Bonab, R. G. Tompkins and A. J. Fischman, J. Surg. Res., 2014, 188, 473-479.

15 T. Tominaga, H. Ito, Y. Ishikawa, R. Iwata, K. Ishiwata and S. Furumoto, J. Labelled Compd. Radiopharm., 2016, 59, 117-123.
16 D.-Y. Kim and J.-J. Min, Nucl. Med. Mol. Imaging, 2016, 50, 185-195.

17 J. Zielonka, J. Joseph, A. Sikora, M. Hardy, O. Ouari, J. Vasquez-Vivar, G. Cheng, M. Lopez and B. Kalyanaraman, Chem. Rev., 2017, 117, 10043-10120.

18 T. Mou and X. Zhang, Molecules, 2017, 22, 562.

19 A. Haslop, L. Wells, A. Gee, C. Plisson and N. Long, Mol. Pharm., 2014, 11, 3818-3822.

20 S. R. Banerjee and M. G. Pomper, Appl. Radiat. Isot., 2013, 76, 2-13.

21 L. Martiniova, L. De Palatis, E. Etchebehere and G. Ravizzini, Curr. Radiopharm., 2016, 9, 187-207.

22 V. Sharma, J. Sivapackiam, S. E. Harpstrite, J. L. Prior, H. Gu, N. P. Rath and D. Piwnica-Worms, PLoS One, 2014, 9, e109361.

23 M. Kardashinsky, N. Lengkeek and L. M. Rendina, J. Labelled Compd. Radiopharm., 2017, 60, 4-11.

24 A. J. Smith, P. J. Gawne, M. T. Ma, P. J. Blower, R. Southworth and N. J. Long, Dalton Trans., 2018, 47, 15448-15457.

25 A. J. Smith, B. E. Osborne, G. P. Keeling, P. J. Blower, R. Southworth and N. J. Long, Dalton Trans., 2020, 49, 1097-1106.

26 E. W. Price and C. Orvig, Chem. Soc. Rev., 2014, 43, 260290.

27 M. I. Tsionou, C. E. Knapp, C. A. Foley, C. R. Munteanu, A. Cakebread, C. Imberti, T. R. Eykyn, J. D. Young, B. M. Paterson, P. J. Blower and M. T. Ma, RSC Adv., 2017, 7, 49586-49599.

28 E. Mariotti, M. Veronese, J. T. Dunn, R. A. Medina, P. J. Blower, R. Southworth and T. R. Eykyn, EJNMMI Res., 2013, 3, 74.

29 M. G. Handley, R. A. Medina, E. Mariotti, G. D. Kenny, K. P. Shaw, R. Yan, T. R. Eykyn, P. J. Blower and R. Southworth, J. Nucl. Med., 2014, 55, 488-494.

30 F. Shaughnessy, E. Mariotti, K. P. Shaw, T. R. Eykyn, P. J. Blower, R. Siow and R. Southworth, EJNMMI Res., 2014, 4, 1-10.

31 R. A. Medina, E. Mariotti, D. Pavlovic, K. P. Shaw, T. R. Eykyn, P. J. Blower and R. Southworth, J. Nucl. Med., 2015, 56, 921-926.

32 K.-P. Eisenwiener, M. I. M. Prata, I. Buschmann, H.-W. Zhang, A. C. Santos, S. Wenger, J. C. Reubi and H. R. Mäcke, Bioconjugate Chem., 2002, 13, 530-541.

33 World Intellectual Property Organization, WO2010/ 066051A1, 2010, 1-35.

34 Y.-S. Kim, Z. He, W.-Y. Hsieh and S. Liu, Bioconjugate Chem., 2007, 18, 929-936.

35 S. E. Abu-Gosh, N. Kolvazon, B. Tirosh, I. Ringel and E. Yavin, Mol. Pharm., 2009, 6, 1138-1144.

36 R. L. Gallo, J. N. Finkelstein and R. H. Notter, Biochim. Biophys. Acta, 1984, 771, 217-227.

37 R. Southworth and P. B. Garlick, Am. J. Physiol.: Heart Circ. Physiol., 2003, 285, H316-H324.

38 M. J. Frisch, G. W. Trucks, H. B. Schlegel, G. E. Scuseria, M. a. Robb, J. R. Cheeseman, G. Scalmani, V. Barone, 
G. a. Petersson, H. Nakatsuji, X. Li, M. Caricato, a. V. Marenich, J. Bloino, B. G. Janesko, R. Gomperts, B. Mennucci, H. P. Hratchian, J. V. Ortiz, a. F. Izmaylov, J. L. Sonnenberg, D. Williams, F. Ding, F. Lipparini, F. Egidi, J. Goings, B. Peng, A. Petrone, T. Henderson, D. Ranasinghe, V. G. Zakrzewski, J. Gao, N. Rega, G. Zheng, W. Liang, M. Hada, M. Ehara, K. Toyota, R. Fukuda, J. Hasegawa, M. Ishida, T. Nakajima, Y. Honda, O. Kitao, H. Nakai, T. Vreven, K. Throssell, J. a. Montgomery Jr., J. E. Peralta, F. Ogliaro, M. J. Bearpark, J. J. Heyd, E. N. Brothers, K. N. Kudin, V. N. Staroverov, T. a. Keith,
R. Kobayashi, J. Normand, K. Raghavachari, a. P. Rendell, J. C. Burant, S. S. Iyengar, J. Tomasi, M. Cossi, J. M. Millam, M. Klene, C. Adamo, R. Cammi, J. W. Ochterski, R. L. Martin, K. Morokuma, O. Farkas, J. B. Foresman and D. J. Fox, Gaussian 16, Revision C.01, Gaussian, Inc., Wallin, 2016.

39 J.-D. Chai and M. Head-Gordon, Phys. Chem. Chem. Phys., 2008, 10, 6615.

40 G. Scalmani and M. J. Frisch, J. Chem. Phys., 2010, 132, 114110.

41 W. R. Wadt and P. J. Hay, J. Chem. Phys., 1985, 82, 284-298. 